\title{
Challenges and Benefits of Sustainable Industry 4.0 for Operations and Supply Chain Management-A Framework Headed toward the 2030 Agenda
}

\author{
Rodrigo Goyannes Gusmão Caiado ${ }^{1}$ (D), Luiz Felipe Scavarda ${ }^{1} * \mathbb{D}$, Bruno Duarte Azevedo ${ }^{1}$, \\ Daniel Luiz de Mattos Nascimento ${ }^{2}$ (D) and Osvaldo Luiz Gonçalves Quelhas ${ }^{3}$ (D)
}

Citation: Caiado, R.G.G.; Scavarda, L.F.; Azevedo, B.D.; de Mattos Nascimento, D.L.; Quelhas, O.L.G. Challenges and Benefits of Sustainable Industry 4.0 for Operations and Supply Chain Management-A Framework Headed toward the 2030 Agenda. Sustainability 2022, 14, 830. https:// doi.org/10.3390/su14020830

Academic Editor: Andrea Appolloni

Received: 21 November 2021

Accepted: 7 January 2022

Published: 12 January 2022

Publisher's Note: MDPI stays neutral with regard to jurisdictional claims in published maps and institutional affiliations.

Copyright: (C) 2022 by the authors. Licensee MDPI, Basel, Switzerland. This article is an open access article distributed under the terms and conditions of the Creative Commons Attribution (CC BY) license (https:// creativecommons.org/licenses/by/ $4.0 /)$.
1 Industrial Engineering Department, Pontifical Catholic University of Rio de Janeiro (PUC-Rio), Rio de Janeiro 22541-041, Brazil; rodrigocaiado@puc-rio.br (R.G.G.C.); brunodazevedo@yahoo.com.br (B.D.A.)

2 Business Organisation, Marketing and Sociology Department, University of Jaén, 23700 Linares, Spain; dmattos@ujaen.es

3 Sustainable Management Systems Department, Federal Fluminense University, Niterói 24210-240, Brazil; osvaldoquelhas@id.uff.br

* Correspondence: lf.scavarda@puc-rio.br

\begin{abstract}
Currently, Industry 4.0 (I4.0) represents a worldwide movement to improve the productivity and efficiency of operations and supply chain management (OSCM), which requires rethinking and changing the mindset of the way in which products are manufactured and services are used. Although the concept of I4.0 was not popularised in the ratification of the 2030 Agenda, I4.0 is a watershed in the implementation of the Sustainable Development Goals (SDGs). It can serve as a platform for the alignment of the SDGs with the ongoing digital transformation. However, the challenges to the integration of I4.0 and sustainability in OSCM, and the benefits of this integration, in line with the SDGs, remain unclear. Moreover, there is a lack of a standard structure that establishes links between these challenges and benefits to strategically guide organisations on the journey towards a sustainable OSCM 4.0 (S-OSCM4.0) aligned with the SDGs. Thus, the purpose of this paper is to propose an S-OSCM4.0 framework for organisations to attain sustainability and I4.0 in OSCM, in line with the 2030 Agenda. Based on a systematic literature review, 48 articles that complied with the selection criteria were analysed using content analysis. The research findings were synthesised into taxonomies of challenges and benefits, and these categories were linked into a step-by-step framework, following an inductive approach. The proposed framework represents a novel artefact that integrates taxonomies in order to holistically achieve sustainable digitalisation for people, prosperity and planet benefits, and sheds light on the potential contributions of S-OSCM4.0 to the SDGs.
\end{abstract}

Keywords: sustainable digitalisation; sustainable development goals; people; planet and prosperity; operations and supply chain management (OSCM); taxonomy development

\section{Introduction}

Industry 4.0 (I4.0) emerged recently, and is already considered a theoretical structural revolution for operations and supply chain management (OSCM) with significant improvements in productivity and efficiency in manufacturing systems [1,2]. I4.0 is a sociotechnical concept $[3,4]$ that can support industry and overall society in the achievement of sustainable development (SD) [5]. I4.0 is important in the history of society's evolution in terms of technologies, being called the fourth industrial revolution, a technological milestone that promotes changes in theory and practice related to industry's evolution [6]. This is in line with the demand for manufacturing organisations to produce economically, environmentally and socially sustainable goods [6,7], resulting in the implementation of different sustainability concepts and practices in OSCM [8]. Therefore, sustainability is a crucial component for OSCM [9]. 
I4.0 and sustainability have been associated, aiding OSCM scholars and practitioners in developing a more sustainable culture [10]. Although the concept of I4.0 was not so popular in the ratification of the 2030 Agenda for SD, I4.0 remains a landmark in the implementation of the sustainable development goals (SDGs) through information and communication technologies (ICTs) [11]. Thus, as stated in [3], I4.0 can offer a great chance to align the SDGs with the digital transformation which is underway in industrial development, which also carries the potential to become a threat if sustainability goals are not taken into account during the implementation of I4.0. Within this context, organisations should implement digital technologies and reinforce the focus on sustainability with regard to improving their performance and meeting their goals [12,13].

Although much has been carried out within this topic, there is a need for additional studies that embrace I4.0 in OSCM [1,2] and I4.0 with regard to sustainability [14]. Moreover, there is a need in the literature to understand the interrelation between I4.0 and sustainable OSCM (S-OSCM) [15], and how I4.0 can aid in achieving S-OSCM [16]. While it is essential to understand the underlying dynamics of the implementation of I4.0, which requires new mindsets to deal with the challenges of digital transformation; there are still few studies focusing on the challenges of the implementation of I4.0 in companies [17]. The problem statement concerns the inexistence of works that integrate I4.0 practices and SDGs to improve sustainability in OSCM $[18,19]$. Therefore, there is a research gap in the literature of works that integrate I4.0, SDGs and OSCM practices with a framework aimed at the I4.0 implementation technologies favouring sustainability $[20,21]$. In a complementary way, considering the challenges of I4.0 (e.g., data quality and credibility, unemployment, complexity problems, less human control and more significant adverse environmental impacts), rigorous research is needed to address the implications of sustainability in intelligent industrial value chain systems based on I4.0 [10]. It is becoming necessary to identify the crucial factors that obstruct the successful alignment of S-OSCM and I4.0, which have been reported by many studies in the form of barriers, failure factors and challenges [8,22]. In this vein, there is a need to identify the challenges in order to align sustainability and digital issues towards S-OSCM4.0.

Most studies on the I4.0 digital transformation have focused on the technical aspect of architecture design for integration to implement I4.0. Consequently, the sustainability aspects have not been researched comprehensively, and possible potentials have not been identified [3]. Unlike sustainable initiatives, in general, I4.0 technologies do not consider the social and environmental dimensions of sustainability, and ignore the sustainable value of products or the ecological risk of digital transformation processes [23]. Furthermore, while the potential benefits of integrating digital technologies and SCM have been widely reported by academics and practitioners $[9,24]$, less is known regarding the current state-ofthe-art literature on S-OSCM 4.0's benefits. In this sense, there is a need to investigate the benefits of S-OSCM 4.0's implementation, which is made even more intense from the triple bottom line (TBL) perspective [25].

Within this context, there is a need to address sustainability in OSCM within I4.0 [12], aiding different organisations to implement S-OSCM successfully beyond traditional and sustainability supply chain practices [8]. Few frameworks in the literature related to the adoption of sustainability in OSCM focus on the link between challenges and solution measures based on I4.0 [8,16,22,26,27]. For instance, [8] developed a framework that links sustainable supply chain management (SSCM) challenges with their solution measures. However, none of the frameworks available in the literature manage to establish links between the challenges to the integration of I4.0 and sustainability in OSCM in order to generate and obtain the S-OSCM4.0 benefits associated with the 2030 Agenda.

Few studies link the taxonomies of benefits and challenges [25]. It is highly critical to explore the association between the taxonomies [28]. Still, the literature available to sustainable I4.0 adoption focuses on proposing a taxonomy without linking the concepts to provide a holistic perspective, which is necessary to the SDGs. For example, Ref. [10] provided taxonomies of challenges for effective I4.0 initiatives for supply chain sustainability. 
The gaps in the existing literature led to the development of the following research questions (RQs), which will direct this paper:

RQ1: What is the current state of the challenges for S-OSCM4.0?

RQ2: Considering the SDGs, what are the benefits of integrating I4.0 with sustainability in OSCM?

RQ3: How can the interplay between S-OSCM4.0 challenges and benefits leverage the achievement of the SDGs?

Within this context, the purpose of this paper is to develop a new S-OSCM4.0 taxonomybased framework to help organisations to introduce sustainability and I4.0 into OSCM in line with 2030 Agenda by aligning the challenges for I4.0-sustainability integration in OSCM and sustainable I4.0's benefits, with regard to the 2030 Agenda (\#17 SDGs). Finally, it also attempts to establish the causal relationships between the S-OSCM4.0 and the SDGs, providing testable propositions about these relationships. Thus, this research meets the lack of studies combining multiple taxonomies (e.g., challenges and benefits) towards S-OSCM4.0 in line with Agenda 2030. This framework is seen as a platform for achieving the SDGs, and should help organisations balance the need for operational excellence in their production and service systems while remaining committed to environmental concerns and social justice.

Therefore, this research offers different contributions. First, the fragmented literature in I4.0 and S-OSCM is analysed, synthesised, and integrated through a novel and rigorous systematic literature review (SLR). Furthermore, it offers a holistic and integrated vision of sustainability that explores the sustainable OSCM from the perspective of UN SDGs, and through an inclusive and sustainable digital transformation of the industry, expanding the accumulated knowledge on sustainable I4.0 with a particular focus on digitally activated S-OSCM, aiming to fill the gaps in the literature highlighted previously [28,29]. Moreover, it is one of the few embryonic studies in the OSCM domain that proposes taxonomies of challenges for integrating I4.0 and sustainability, and the benefits of the interplay between I4.0 and sustainability in OSCM. An iterative taxonomy development approach was used as a proposal to classify and organise the relevant body of knowledge [28] belonging to S-OSCM4.0. This new area requires greater clarity and a theoretical understanding of challenges and benefits, and the relationship of these categories.

The present study possesses strong theoretical and practical implications regarding the domain of OSCM, particularly sustainable operations, supply chains and Industry 4.0 streams of research [7]. The findings of the SLR in the form of the proposed taxonomy-based framework is one of the initial efforts to contribute to the theory of S-OSCM4.0 and the relationships between the challenges and benefits. It proposes that the implementation of S-OSCM 4.0 leads to the unlocking of the SD benefits in line with the SDGs. Hence, this study makes a significant theoretical contribution to the literature in the form of a detailed SLR on S-OSCM4.0 that generates two deliverables: taxonomies and the framework [30]. This taxonomy can be used to improve the specification of interventions in the S-OSCM4.0 field, thus improving replication, implementation, and evidence syntheses. We propose an S-OSCM4.0 framework based on the findings of the literature, with challenges and benefits as the critical components of this framework.

The framework will act as a ready reckoner for the practitioners (and policymakers) in the field of OSCM while developing the guidelines for the implementation of sustainable digitalisation. Thus, the framework will guide practitioners towards the implementation of S-OSCM4.0, and they will acknowledge the challenges of the integration of I4.0 and sustainability that need to be overcame in order to obtain SD benefits in OSCM. The proposed framework sheds light on the potential of sustainable I4.0 in terms of the maximization of company contributions to the SDGs, aligning their course in order to ensure that sustainability is an outcome of the core business strategy.

In order to achieve its goal, this paper is structured into five sections. After this introduction, Section 2 describes the adopted research methodology. Section 3 presents the study results, including the study descriptors, and categorises and analyses two taxonomies (i.e., 
challenges and benefits) revealed in the literature. Section 4 offers the discussions, presenting the proposed S-OSCM4.0 framework, outlining the interplay between the taxonomies and their elements, and highlighting seven research propositions to align S-OSCM4.0 priorities with the 2030 Agenda. Section 5 closes the paper with the concluding remarks and potential avenues for future research.

\section{Materials and Methods}

This research adopts an SLR [31], a rigorous methodological process that results in the selection of the most relevant articles, thus reducing the possibility of losing important information [32]. According to [33], the preparation and maintenance of a systematic review involves seven steps: (i) the formulation of the problem, (ii) the location and selection of the studies, (iii) the assessment of the quality of the studies, (iv) the collection of the data, (v) the analysis and presentation of the results, (vi) the interpretation of the results, and (vii) the improvement and updating of the revisions. However, according to research in the field of operations management (OM) [34-36], SLR consists of five consecutive phases: (1) question formulation, (2) study location, (3) study evaluation and selection, (4) analysis and synthesis, and (5) the reporting and usage of the results. Furthermore, according to $[37,38]$, SLR has several advantages compared to other review methods; among them, the adoption of a replicable and transparent method that minimizes errors and biases, and improves the quality and validation of the process. It is noteworthy that [37] included a new stage of validation and coding that advocates the division of the review among authors to assess possible differences and ensure inter-rater reliability. For [34], the review will only be classified as systematic if it adheres to the following principles: (1) it is conducted using a systematic system or method, (2) it presents a transparent and explicit method, (3) it is replicable and updateable, (4) it summarizes and synthesizes the evidence relating to the review question. Therefore, considering these facts arising from the literature, it is noteworthy that the SLR is the most adequate method to identify, through a high-quality process, I4.0, SDGs and OSCM practices which favour sustainability.

This review was conducted according to the systematic review process presented by [39], for OM, through the following four stages [40]: (1) the formulation of the research questions, (2) the selection and evaluation of the studies, (3) the analysis of the content of the selected articles, and (4) the description of the results. In the first stage, we formulated the research problem together with the RQs and the aims of this review, which are delineated in Section 1.

The second stage comprised the literature search by selecting electronic databases (EDs) and identifying keywords, which is critical to a comprehensive and unbiased review. According to [39], at least two databases should be searched. The EDs used were Scopus and Web of Science (WoS) due to their complementarity [41]; we applied an extensive set of terms combined with the Boolean expressions "AND" and "OR". Table 1 presents the search keywords with the number of documents associated with the database. The research was conducted by combining the search terms in the titles, abstracts or keywords, and was limited to papers published in peer-reviewed journals in English up to September 2020, when they were available (including as in press), in both engineering and business fields, regarding the subject of the search. 
Table 1. Search strings used in Scopus and WoS.

\begin{tabular}{|c|c|c|c|}
\hline ED & Search ID & Search String & Results \\
\hline \multirow{2}{*}{ Scopus } & 1 & $\begin{array}{c}\text { ((“Industry 4.0" OR “Smart manufacturing”) AND (“SDGs" } \\
\text { OR "sustainable development goals")) }\end{array}$ & 25 \\
\hline & 2 & $\begin{array}{c}\text { ((“Industry 4.0" OR “Smart manufacturing") AND (“sustainab } \\
\text { * " OR "green") AND ("supply chain" OR "SCM")) }\end{array}$ & 125 \\
\hline \multirow{2}{*}{ WoS } & 1 & $\begin{array}{c}\text { (("Industry 4.0" OR “Smart manufacturing") AND ("SDGs" } \\
\text { OR "sustainable development goals")) }\end{array}$ & 12 \\
\hline & 2 & $\begin{array}{c}\text { ((“Industry 4.0” OR “Smart manufacturing") AND } \\
\text { ("sustainab*” OR “green”) OR (“"supply chain” OR “SCM")) }\end{array}$ & 91 \\
\hline
\end{tabular}

* it represents variations upon the radical "sustainab" such as sustainability, sustainable etc.

By analysing the number of duplicate articles, 105 articles were found in both databases. A trained team was created, and was involved in all of the major stages of the process, as multiple reviewers should ensure transparency [39]. Firstly, the abstracts were read, and 36 articles were excluded because they did not address the scope of the integration of I4.0 and sustainability in OSCM, as well as the combination of digital transformation and sustainable development in manufacturing and supply chains, or the interplay between I4.0 and SDGs from the perspective of organisations or industries. In this study, the integration of I4.0 and S-OSCM was represented by the adoption of digital technologies and modern sustainability practices to leverage sustainable Industry 4.0 [15], which means an inclusive digital transformation through the alignment of the organisations' priorities with the 2030 Agenda. In addition, digital transformation is the path towards the digitalisation of processes and operations within organisations [2]. In the I4.0 era, sustainable development encompasses the operationalisation of TBL sustainability [42], embracing trade-offs between environmental, social, and economic dimensions in OSCM, using sustainable technological solutions built on the I4.0 sociotechnical system. In this vein, the interplay between I4.0 and SDGs is an attempt to identify the synergetic points between these perspectives in order to understand how the I4.0 technologies can add value to the integrated TBL dimensions and obtain the SDGs, as well as the way in which this agenda contributes to the reshaping of OSCM, through a sustainable digitalisation.

The third stage studied the analysis, and consisted of the evaluation of the content of the 69 selected articles, where 24 were excluded because they did not present any challenge or benefit of the I4.0-sustainability integration in the OSCM domain, resulting in 45 articles. The procedure was complemented with the use of the forward and backward snowball technique, as recommended in [39]. This allowed for the capture of three more documents which were pertinent to this research. Finally, the sample of articles considered adequate for this research comprised 48 documents. Figure 1 describes the process of including and excluding articles during the four stages given in [40], according to the PRISMA protocol (Preferred Reporting Items for Systematic Reviews and Meta-Analyses) [43]. 


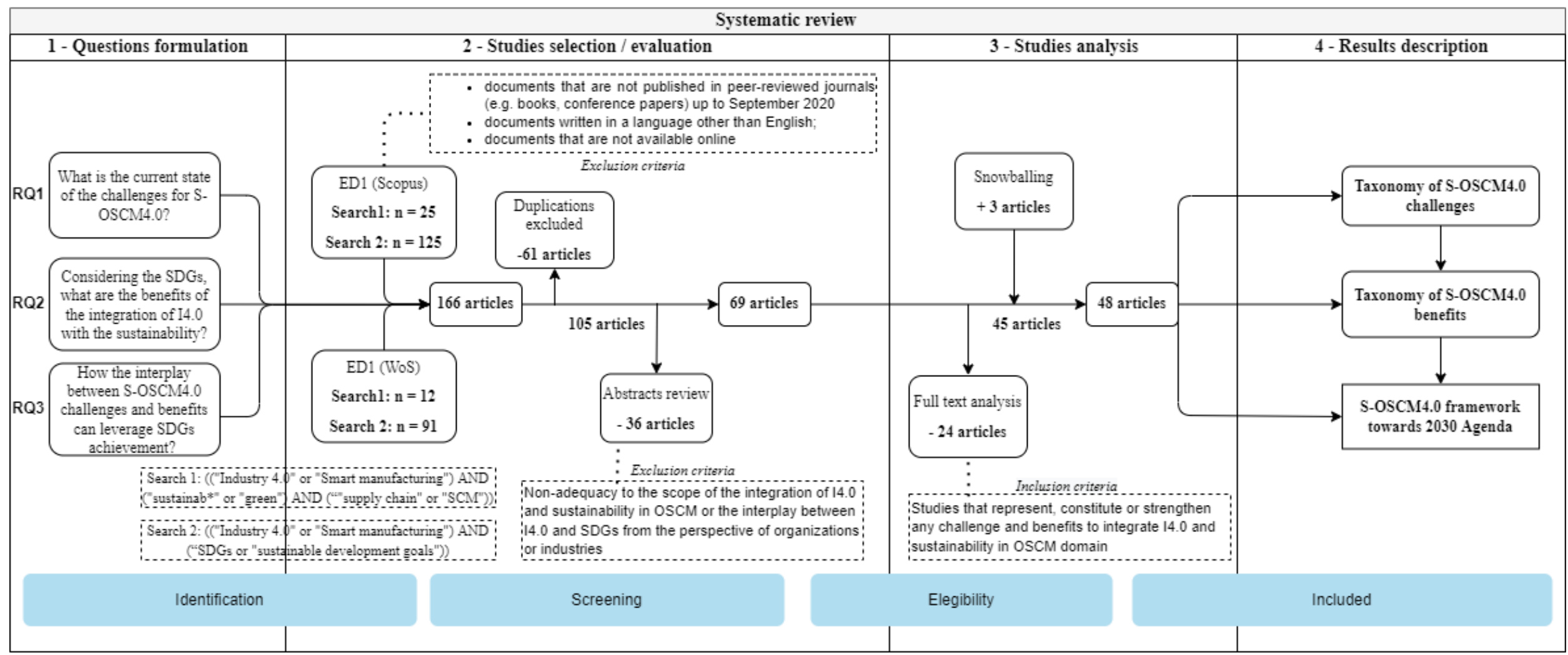

Figure 1. Flowchart of the research methodology: adapted from $[40,43]$. 
After identifying the relevant articles, the data gathering considered a concept matrix, using a Microsoft Excel worksheet, in which the articles were coded according to their bibliographic characteristics, and this matrix was used for the data analysis, synthesis, and interpretation. Thus, at the fourth stage, the results were analysed using a content analysis [43] guided by [44,45], in which each document from the selected literature was evaluated systematically and critically [46] by the authors. Then, they were synthesised into taxonomies and a conceptual framework [30] following an iterative taxonomy development approach, as presented in Figure 2.

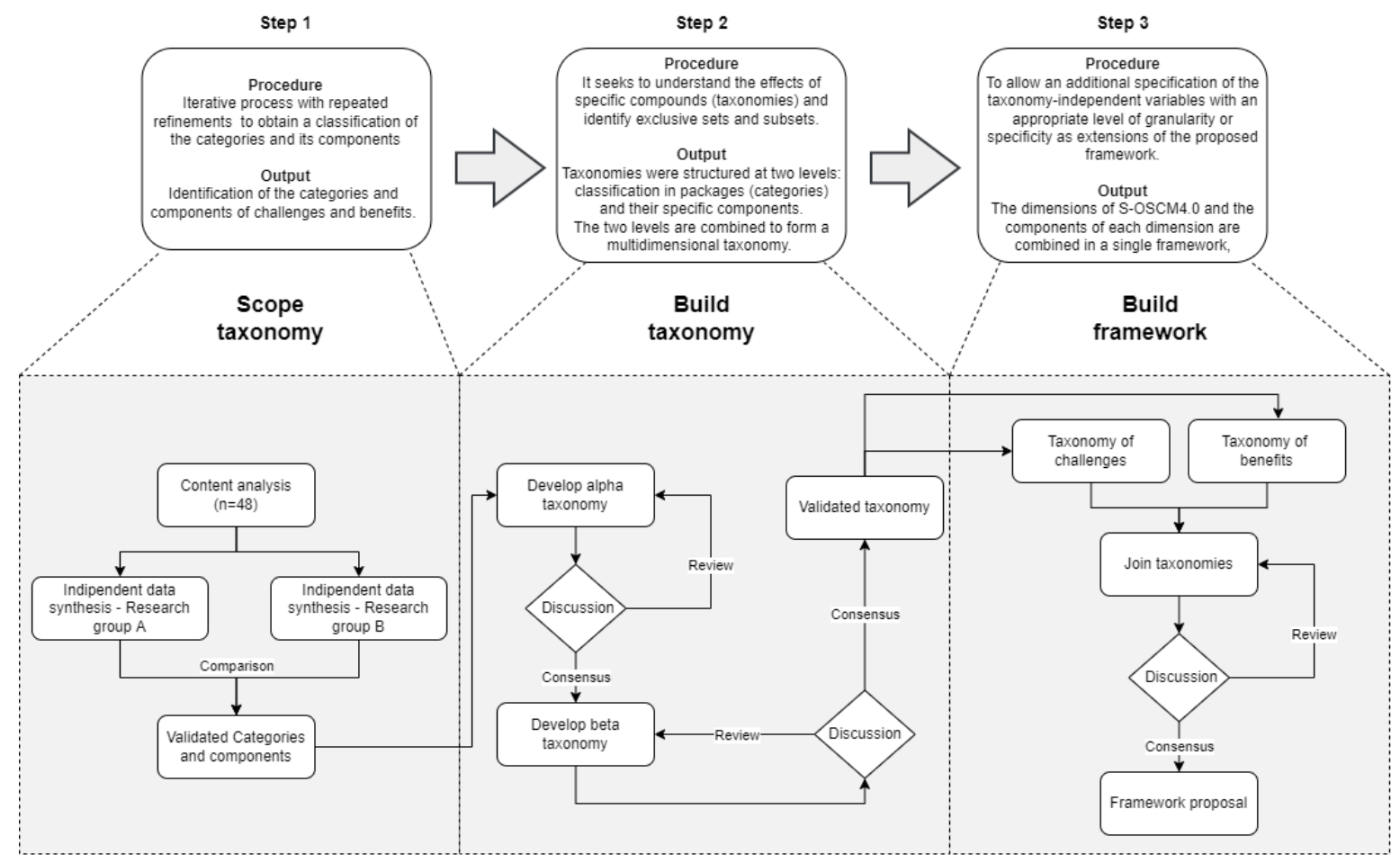

Figure 2. Taxonomy development and integration: adapted from [28].

In order to structure taxonomies and their relationship (within the framework), the three steps of [28] were followed. First, the elements were heuristically aggregated into an iterative process with repeated refinements to increase their internal homogeneity and generality, in order to classify the categories and components of the challenges and benefits. In this step, the research team (five authors of this paper) was divided into two groups and one moderator (research supervisor), each one with two researchers, following a systematic method with a conceptual-to-empirical approach in which, from the content analysis, the categories and components were synthesised into groups A and B. Then, the data were compared and checked to seek validated elements.

Then, the authors aimed to understand the effects of the specific packages which constitute the various categories, and to identify exclusive sets and subsets of challenges and benefits. The taxonomies were built at two levels, with the classification into packages being the first, or more inclusive, level of generality in S-OSCM4.0, and the second level consisting of the specific components and subcomponents of each of these dimensions (categories). In this step, an alpha taxonomy was first developed, which was presented to the research team and suffered some adjustments after two rounds of discussions before they reached a consensus. Then, a beta taxonomy was developed, and after one last round of discussion with the group, for the reviewing of the ending conditions and validation, the taxonomies were built [47]. The taxonomies followed the three criteria of [48], which are: (i) to be consistent with reality (e.g., to be accurate to OSCM organisational settings); (ii) to demonstrate the interaction (interdependence) between the attributes selected with 
the OSCM domain; and (iii) to demonstrate comprehensiveness (e.g., to be useful for multiple organisations).

Finally, in the third step, the two levels were combined to form a multidimensional taxonomy of S-OSCM4.0. The components of the two proposed dimensions were incorporated into a single framework to assist in the operationalization of sustainable development in operations and supply chains along the lines of the 2030 Agenda. This last step also considered one round of discussion to refine and propose a taxonomy-based framework following an inductive approach $[45,49]$, which also included an iterative process of building, testing, revising, and constantly comparing categories and data, and involved the research team of this paper. The reporting of these results is covered in Sections 3 and 4 , and the appendixes.

\section{Results}

This section presents the study descriptors and the taxonomies of the challenges and benefits.

\subsection{Study Descriptors}

This section presents a panoramic perspective on the topic through descriptive analysis. Appendix A provides a summary of the articles reviewed. The SLR process yielded 48 articles that met the eligibility criteria for the analysis. The convergence of sustainability and I4.0 in the OSCM domain is a topic that has evolved in recent years, and the papers distribution (Figure $3 a, b$ ) indicates that higher numbers of articles were published over the last four years, and the peak was reached in 2020, with 21 articles. The interest in researching the sustainability aspects of I4.0 in OSCM is increasing in popularity, which is an evolutionary trend which is compatible with a new research field [15].

Figure 3a shows the distribution of the studies based on the research categories (theoretical, empirical, or mixed) for each year of publication. There is a predominance of theoretical studies, but from 2019 onwards, there was an increase in mixed research. As a still under-explored, emerging research field, the studies are still going through theoretical approaches (e.g., literature reviews) as the knowledge of the concepts of the S-OSCM4.0 still needs to be consolidated well. Figure $3 b$ presents the chronological distribution of the publications considering the research approach (qualitative, quantitative, or mixed). According to Figure $3 \mathrm{~b}$, the most used approach in the analysed articles is the qualitative approach, followed by mixed and quantitative papers. Notably, only $4.17 \%$ of the sample adopted a quantitative approach alone, and from 2020 onwards there was an increase of studies combining qualitative and quantitative (mixed) approaches. This can also indicate the recentness of the subject; as it acquires maturity, new methodological approaches will start to be used (e.g., multiple-criteria decision-making methods) and combined.

In terms of I4.0 technologies for S-OSCM, considering the technologies pointed out in [2], Figure 4 shows that over half of the articles (52.08\%) involved multiple technologies, in which base technologies were predominant (Internet of things, cloud computing and bigdata analytics) [50], followed by the general category (39.29\%), which means that the paper does not go into detail about one or several technologies, and that it has a more simple approach to the subject. It should also be noted that among the I4.0 technologies, big-data analytics (BDA) are the technology with the most studies; within the multiple technologies category, this technology has also been widely discussed in the context of sustainability, which reveals a growing interest in BDA for sustainable business management [9]. 
research category

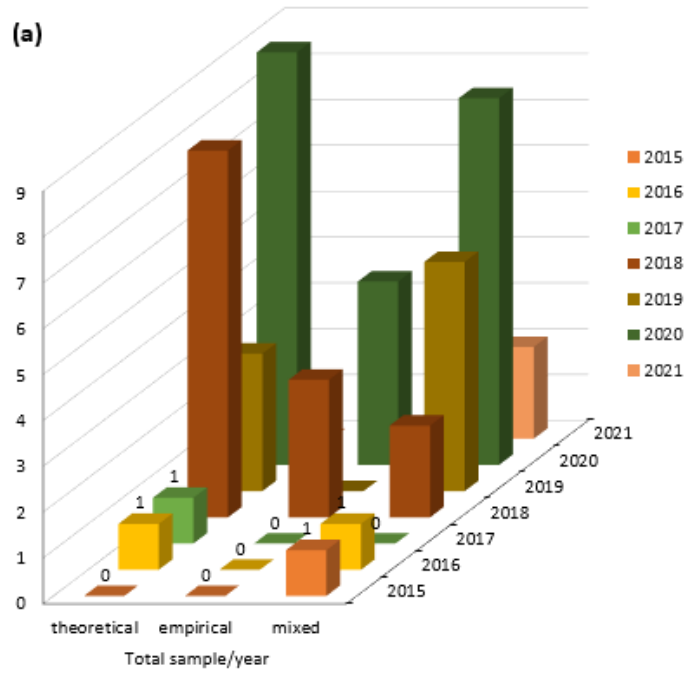

research approach

(b)

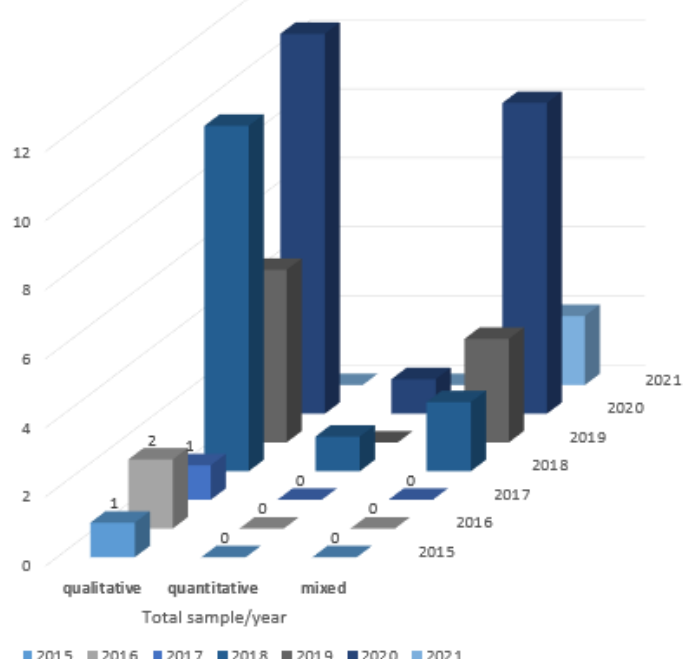

Figure 3. Chronological distribution of the articles based on their research category (a) and research approach (b).

\section{I4.0 Technologies}

Multiple technologies 25

General 11

Big data analytics 5

Blockchain 3

Cyber physical systems

Internet of things 1

Aditive manufacturing /3D printing 1

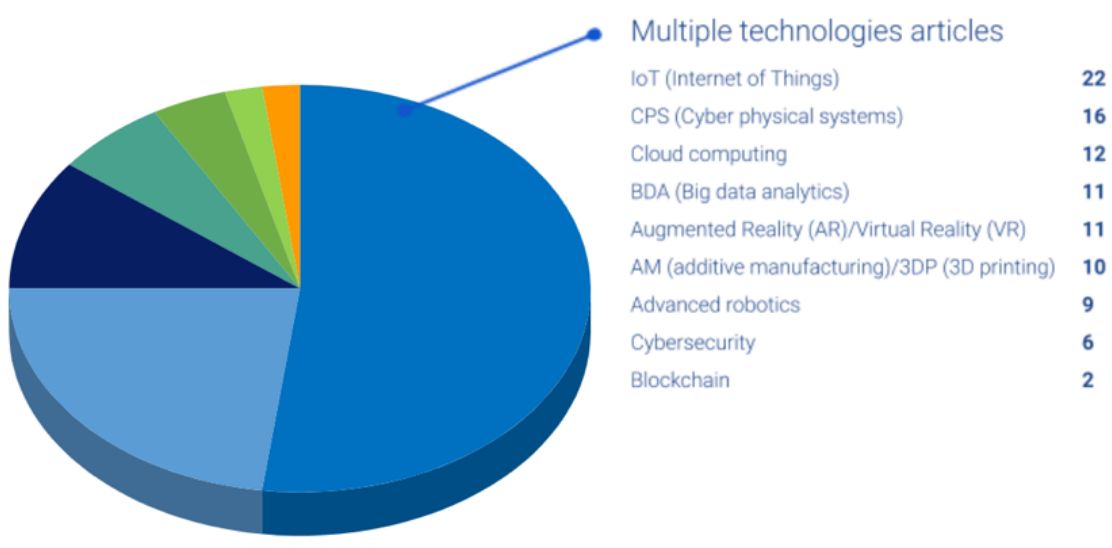

Figure 4. Distribution of studies by I4.0 technology.

Figure 5 presents the number of the publications by the country of affiliation of the analysed sample's authors. The principal geographical location of the studies was the United Kingdom (11 publications), followed by India (10), the United States (8), China (7), Brazil (7), and France (6). It is possible to note that the subject has been studied both by researchers from developing and developing countries, representing a positive initiative, considering that a sustainable digital transformation is a global need that requires the participation and awareness of all regions.

\subsection{Challenges}

The challenges were grouped into 'technology', 'economic', 'society', 'knowledge and support', and 'environment', and they are discussed next. The names of the categories are based on [51]. Appendix A offers the list of papers dealing with each challenge. Figure 6 shows the results of the taxonomy developed for the challenges. 


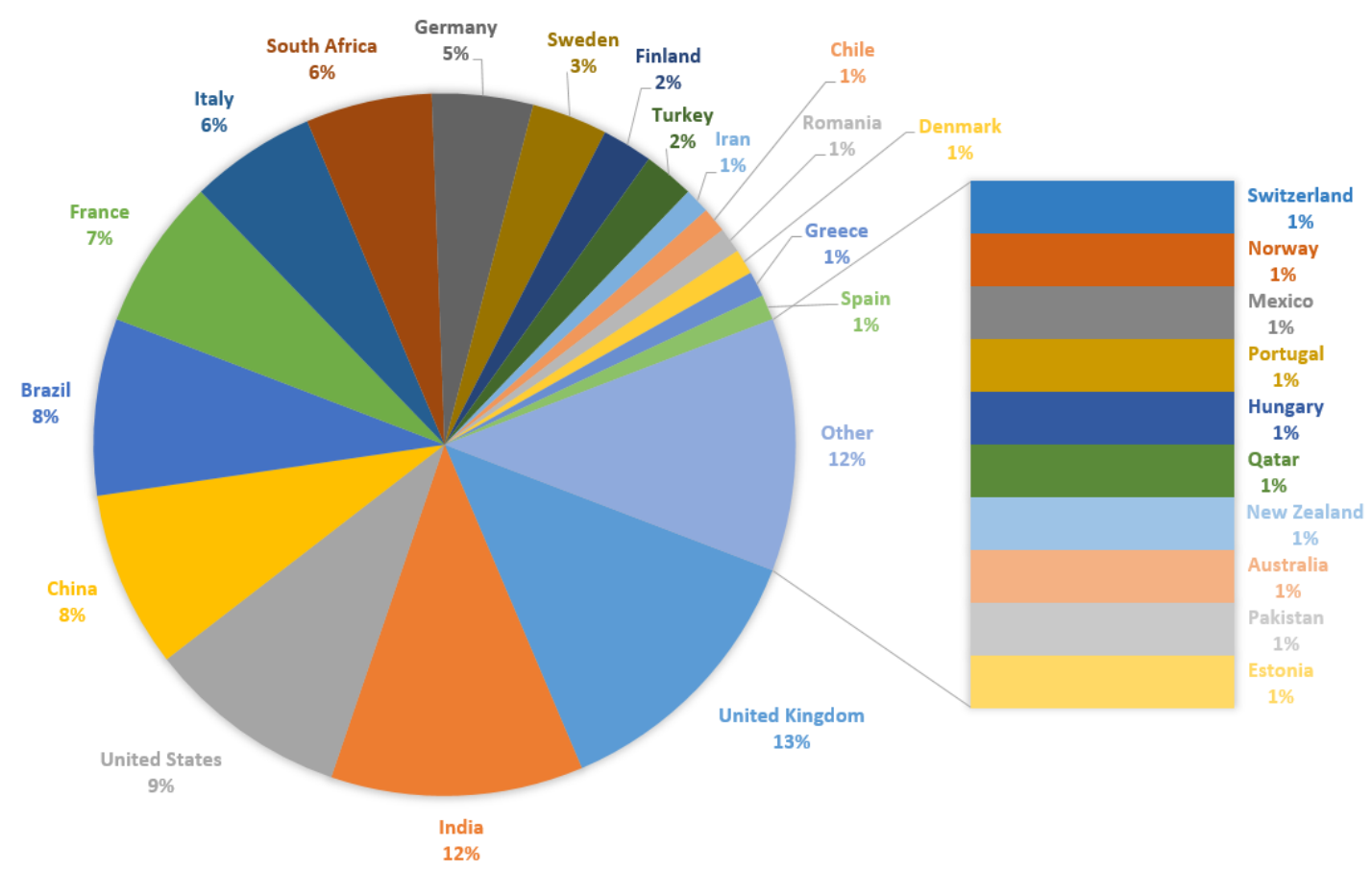

Figure 5. Geographical distribution of the studies.

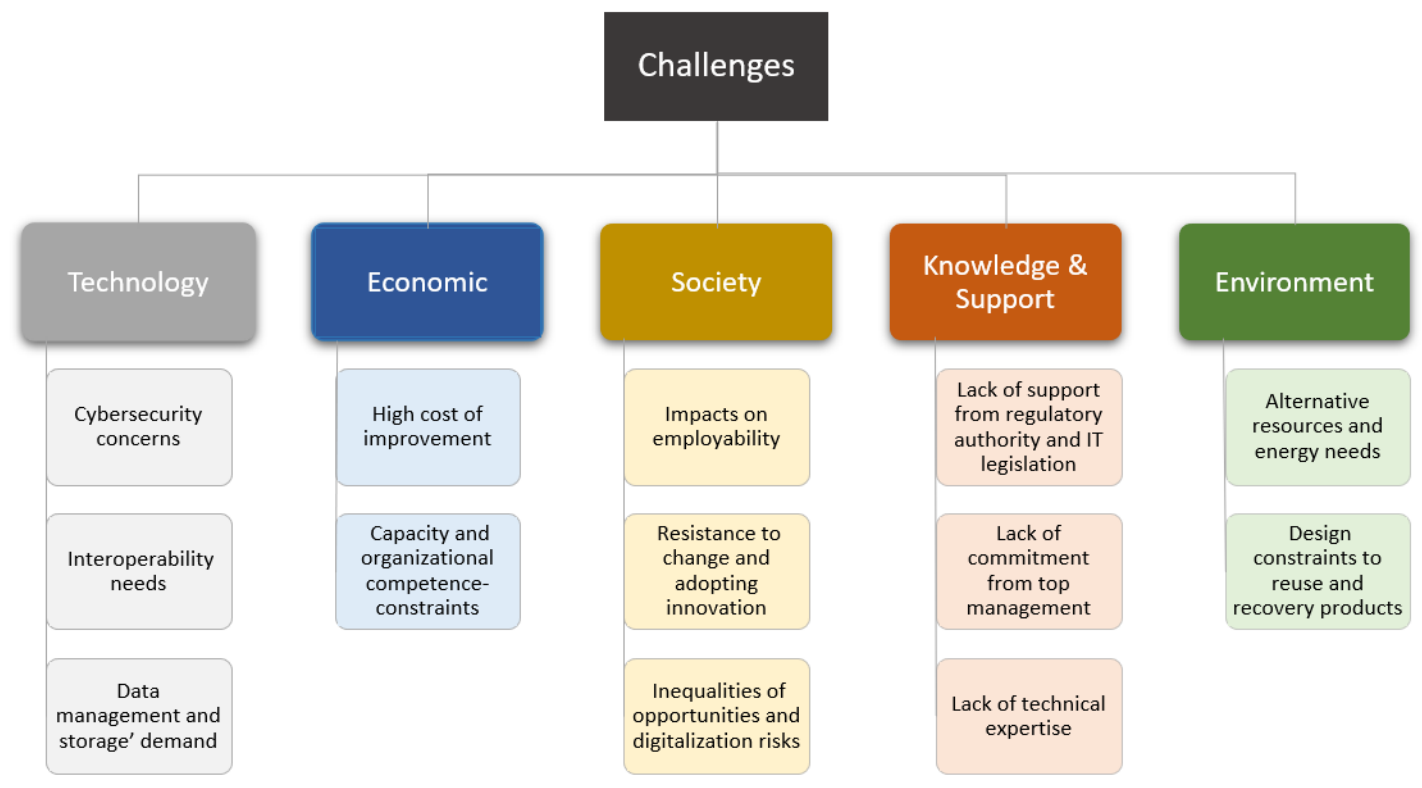

Figure 6. Challenges to S-OSCM4.0.

\subsubsection{Technology}

Cybersecurity concerns are one of the most cited challenges to implementing a sustainable I4.0. There is an increase in critical digital data about individuals that decision-makers can misuse, or which can be targeted by cyber-attacks [14]. Concerns about the inadequate application of IT security standards [16], the lack of trust when integrating IT systems between supply chain partners [5], and the reliability of machine-to-machine (M2M) decisions may arise [52]. According to [26], data breaches and cyber-attacks through malicious software need to be controlled in order to improve the trustworthiness and acceptability of the digital systems. As stated in [53], security is as a challenge and a technological barrier to blockchain technology that impedes its application for business purposes. 
Given the complexity the supply chain [54], and considering that every action has to be integrated into both the business model and logistics across the entire supply chain [55], many authors present interoperability needs as challenges to I4.0 and sustainability. The authors of [5] highlight the low reliability of connectivity between machines and the lack of integration of IT systems between supply chain partners. The authors of [10] discuss the lack of global standards and data-sharing protocols, as well as the lack of integration of technology platforms. The authors of [8] go in the same direction, highlighting the lack of effective communication with suppliers and the nonexistence of a practical framework for SSCM adoption. The authors of [56] list as challenges the lack of a dynamic network infrastructure to link physical and virtual objects, and the centralised management of the heterogeneous lifecycle data. Finally, other authors present other technical issues related to interoperability, such as internet connection and storage requirements [9,24].

Given its high dependency on data, I4.0 has to overcome the challenge of data management and storage in order to be sustainable $[57,58]$. Many problems still need to be addressed. The authors of [10] listed as challenges the poor quality of the existing data, the lack of integration of technology platforms, problems related to coordination and collaboration, and the lack of global standards and data-sharing protocols. Other authors, such as [58,59], stated that data storage challenges blockchain's future applications. Finally, the lack of knowledge about data management between stakeholders [57] and the ineffective management of data acquired during historical product design and development processes [56] are also cited.

\subsubsection{Economic}

The high costs of improvement involved in I4.0 and sustainability are the most significant economic challenge presented in the literature. The investment needed and the capital expenditures underlying I4.0 technologies are quite intense, especially for manufacturing companies located in the context of emerging economies $[18,60]$. To worsenWorseing the situation, there is a lack of funding for technological upgrades [16] and products for which the demand level does not justify the high fixed costs of the I4.0 assembly line [61], and a lack of interest in investing money in sustainability given its long and uncertain amortisation [62]. Ultimately, the challenge is to align an understanding of the requirements of competitiveness with those that represent long-term sustainability [63].

Another challenge for companies is their capacity constraints and organisational competence constraints [64]. The ineffective linkage of sustainability with the existing process structure, ineffective supplier selection strategies, and an ineffective performance measurement system may hinder the integration of I4.0 and sustainability [27]. Ref. [62] presents many risks related to this theme, such as deciding what to invest and when, the changing business models that may lead to the loss of core competencies, customer demands/acceptance; a lack of understanding about data-driven business models, and new competitors.

\subsubsection{Society}

Employability is a challenge associated with society. A smart factory can hinder the opportunity for a labour-intensive workforce, leading to social problems in local communities [52]. Many social risks are involved, such as job losses, shifts of competencies, automation, and the reduction of process steps [62]. Indeed, managing human resources to fit into the I4.0 setup is a considerable challenge for top management [65]. In this sense, the physical and psychological wellbeing of the workers, ageing, and diversity need to be considered [63]. Resistance to change and the adoption of innovation may also be a challenge for society. I4.0 requires policy, infrastructure, societal and environmental changes [54]. These changes may face a lack of management commitment and support [53]; the resistance of culture change [27], including employee and mid-level management resistance [54]; and cultural differences with the supply chain partners [53]. Ref. [64] called these behavioural barriers that demand the managers' strong involvement $[8,22]$. 
Inequalities of opportunities and digitalisation risks were also pointed out as a challenge for society. Given the high investments required to implement I4.0 [57], megacorporations in more developed countries can benefit from the pioneer advantage, increasing wealth disparities in the global consumer market [66]. In this sense, digitalisation may increase global inequalities [67]. Ref. [67] also highlights that the ability to develop countries to catch up not only includes building adequate technological infrastructure but also increasing local knowledge and capabilities through education and training. Access to technological interfaces and knowledge which enable and empower countries and local communities to integrate with and ultimately contribute to the development of the technology and their community is also necessary.

\subsubsection{Knowledge and Support}

The lack of support from the regulatory authority and an absence of strong IT legislation are also challenges for sustainable I4.0 application. The absence of IT security standards and policies may affect both the customer and suppliers in the supply chain network [16]. Furthermore, regulatory and procedural barriers hinder the adoption of SSCM [18]. In addition to legal aspects concerning working time regulations and data protection, [62] also presents political risks such as insufficient infrastructure (Broadband internet; Mobile network) to I4.0. The authors of [59] concluded that the current standards and rules are a limitation for the application of blockchain; therefore, governments may need to formulate policies to either encourage or demand that producers use blockchain systems to improve their environmental sustainability.

The lack of commitment from top management is another challenge for I4.0 and sustainability application/integration. The authors of [10] identified this problem as one of the top six challenges to I4.0 initiatives for a sustainable supply chain in the Indian context. There is a lack of management approval for a significant investment in newer technologies [16], which might be linked to the lack of understanding of the importance of Industry 4.0 at the top management levels [68]. Ref. [57] also mentioned the lack of middleand lower-level managers' support and involvement in the promotion of 'greener' products.

The lack of technical expertise regarding I4.0 technologies is another excellent challenge presented in the literature. There is a need for staff training and education [69], given that society lacks qualified and skilled labour to adapt to I4.0 technologies and sustainability [57]. Ref. [62] cites, as barriers, internal resistance and corporate culture from older employees, which [68] called hesitation to convert to new systems; new requirements for training, mental stress, permanent availability, and missing social interaction with interdisciplinary thinking is needed.

\subsubsection{Environment}

One significant challenge associated with the environment concerns alternative resources and energy needs. The rate of the exploitation of natural resources should not exceed the rate of regeneration [6,70]; however, Industry 4.0 has focused mainly on production and the achievement of the highest profits [69]. The increase in production rates linked to I4.0 led to higher resource and energy consumption, high pollution concerns [66], deforestation, health-related diseases, and ground and water service contamination. Industry 4.0 still involves a high consumption of resources, raw materials, information, and energy, which is environmentally unsustainable [69]. Ref. [58] stated that energy consumption is a significant limitation for blockchain, which aligns with [71], who affirmed that the energy consumption and material quantity of big-data analytics (BDA) negatively impact environmental sustainability.

One of the biggest challenges linked to customised products (a benefit of I4.0) is that the more individualised products become, the harder it is for another company or person to reuse those products [61]. Thus, the design constraints to reuse and recover products are critical challenges. As presented in [18], high-speed innovation can make reuse impossible. Furthermore, there is low management support in the usage of I4.0 
technologies for "design for reuse" philosophy [57]. Therefore, waste might increase, and recycling might become more complex [62]. In addition, the effective management of the knowledge acquired during historical product design and development processes is challenging [56]. This situation is aggravated by the absence of reverse logistics facilities and internal bureaucracy in the creation of a circular logic in the supply chain [27]. Finally, there are some technical limitations. For instance, [18] stated that 3D printing might not provide the surface characteristics specified in the component design or the even material properties, which may demand other processes to be performed.

\subsection{Benefits}

The benefits are aligned with the 2030 Agenda, which is considered to be a plan of action for people, the planet and prosperity. Appendix B offers the list of papers dealing with each benefit, and the linkage of each one to the SDGs and specific targets. Figure 7 shows the result of the taxonomy developed for the benefits.

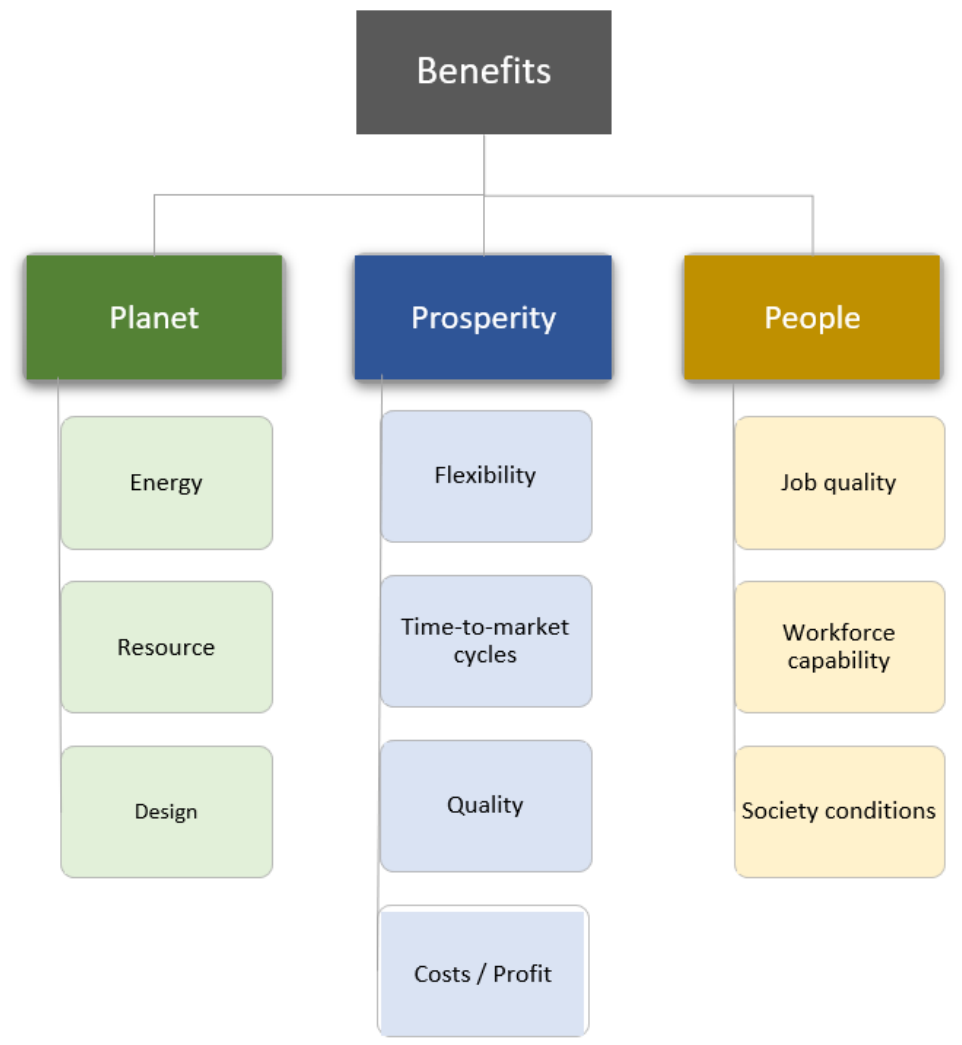

Figure 7. Benefits of S-OSCM4.0.

\subsubsection{Planet}

The adoption of I4.0, with smart production systems, can reduce the energy consumption of companies [72]. Using real-time data from production systems and supply chain partners will mean less and more intelligent energy consumption [73]. As an example, unused electricity from wind power plants can be intelligently distributed at night and used industrially [14]. Additionally, a company's energy consumption can also be reduced through the use of process simulations [62,74], by sharing renewable energy surplus with other plants [75], and by improving throughput times and capacity utilisation [14].

Similarly, to energy reduction, I4.0 adoption can lead to the lower consumption of resources. Virtualisation and the use of intelligent devices in a smart production system enables the reduction of the production of waste [54,66] and overproduction $[14,75]$. Dynamically configurable production processes improve the material efficiency of production, which diminishes the number of materials used [14]. I4.0 can also increase the share of 
reused, remanufactured and recycled materials [54]. As some examples, blockchain facilitates recycling behaviour by incentivizing individuals to participate in deposit-based recycling programs [58]. Additive manufacturing (AM) makes possible the use of waste to generate new value-added products [18].

I4.0 initiatives also have the potential to unlock supply chain sustainability by developing green products [10] through a more sustainable design. Digital technologies can provide efficient solutions for green product design, production and service processes [23]. These new processes can favour easy disassembly for recycling [71]. Furthermore, it is possible to design products with extended life spans by applying the 5Rs strategy (reduce, repair, re-use, recycle, and remanufacture) [73].

\subsubsection{Prosperity}

The advent of Industry 4.0 favours the introduction and the widespread application of new business model innovations, such as Crowd-Sourced Innovation (CSI), Manufacturing as a Service (MaaS), and PaaS [66]. In this sense, process efficiency and data exchange between robots increases innovation [76]. Furthermore, employee development improves the level of knowledge and increases the capability and support of employees to develop green projects [54,63], which shortens innovations [77,78]. I4.0 implantation can reduce set-up times, shorten lead times, and reduce labor and material costs, increasing production flexibility $[63,78]$. Data analytics, machine learning, and artificial intelligence enable the digitalisation and interconnection of industrial processes intended by Industry 4.0 [17]. IoT and AI-based production increase the efficiency and flexibility of production [66]. Cloud manufacturing enables small, flexible-scale production systems with local production networks to be integrated on-demand [64]. AM allows for the production of multiple parts simultaneously in the same build, making it possible to produce an entire product locally [79].

I4.0 can also be a driver for the shortening of time-to-market cycles [77]. For instance, [79] states that 3D printing companies in the wooden furniture industry are free to explore their imagination, which means that they spend a shorter time on market products with more complex shapes. In addition, BDA can assist in decisions regarding the perception and prediction of market demands, sourcing, supply chain network design, product design and development, which provides a faster response to the market and faster decision-making $[9,56]$.

Ref. [61] found that I4.0 leads to increased production efficiency and higher-quality products. This statement is confirmed by many authors, such as [62,79]. The latest presents 3D printing as an enabler for this new reality. According to [69], robotic-assisted production, big-data-driven quality control, and quality assurance teams to analyse proactively will allow all of the business processes that might involve inefficiencies to be eliminated. Digitally enabled infrastructure and multiple data sources can create a differentiated competitive advantage by producing customised products and increasing their perceived values [23].

Finally, cost decreasing/profit improvements are the most cited benefits of adopting digital technologies. Ref. [56] estimated that the combination of BDA and lean management could be worth billions of dollars in improved profits for large manufacturers. Digitalising manufacturing and smarter machines may offer numerous advantages related to cost reduction, such as increasing manufacturing productivity and improving resource efficiency $[23,63,66]$, decreasing inventory and logistics costs [62], reducing operators or manpower, and saving energy [80]. Moreover, BDA allows manufacturers to prepare spare parts for the suitable machine at the right time with the right quantity, optimising the fuel-use efficiency and the real-time route of spare part transportation for suppliers [56].

\subsubsection{People}

For many authors, I4.0 can improve companies' working conditions and environment, and thus job quality. Digitalisation and the emergence of labour-saving technologies (e.g., intelligent robots, autonomous vehicles, and cloud solutions) will eliminate a great part of 
lower-skilled jobs while creating many job opportunities in various areas, such as automation engineering, control system design, machine learning, and software engineering [66]. In many cases, there will be a reduction of monotonous work [17], and employees will be able to work from their homes, ensuring flexibility and reducing pollution [69]. Finally, process automation can lead to safer conditions in the work environment $[26,78,81]$.

According to [13], IoT technologies are better accepted when users have been trained and the workforce has been informed about the expected benefits of the solution. In this sense, it is expected that I4.0 will improve workforce capability through the more practical education of workers [14,78] and a greater number of training courses [80]. As stated in [54], employee development increases knowledge and improves workers' capability and support in green product projects.

The competitive advantage obtained by adopting I.4.0 leads to increased social sustainability by defending the employment levels, producing new job employment opportunities, and paying more taxes on the value delivered [61]. To [80], I.4.0 can improve social conditions, creating employment opportunities for disabled and elderly employees [75]. In addition, open-source-based applications of 3D printing could contribute to sustainable development in rural areas with low economic profiles, as it overcomes the spatial gap to the market of spare parts, consumer products or tools [79].

\section{Discussion}

This section provides the S-OSCM4.0 framework based on the discussion of taxonomies of challenges and benefits, and offers seven research proposals for future studies on S-OSCM4.0, leading to the discussion of the link between S-OSCM4.0 and the 2030 Agenda.

\subsection{S-OSCM4.0 Framework towards the 2030 Agenda}

The S-OSCM 4.0 framework aims to strongly assist practitioners in improving the SSCM adoption rate [18] while also digitalising their operations. It can be used as a guideline to sustainable digitization in OSCM, and can align the organisational activities towards 2030 Agenda. This taxonomy-based framework has a holistic and interdisciplinary view, and suggests that the challenges should be overcome in order to obtain the SD benefits of this integration in line with the SDGs. Figure 8 presents the S-OSCM4.0 framework.

In order to guide an organisation on the journey to S-OSCM4.0, managers should face the challenges of sustainability-I4.0 integration and work on them to obtain SD benefits. As indicated in the study of [82], two main challenges must be overcome: the lack of commitment from top management and the lack of technical expertise, as, according to the authors, top management support is encouraged in order to integrate sustainable development practices into organizations, which it is contingent on the knowledge acquired and applied in OSCM; due to the 2030 Agenda, this pressure to integrate and adopt innovative and cleaner technologies is even greater in emerging countries. In this sense, in order to operationalize the proposed framework, three steps are necessary. The first step (1) consists of the identification of some of the 13 challenges in the five categories (technology, economic, environment, society, and knowledge and support), and facing them with the correct I4.0 adoption to overcome potential restrictions to the integration of I4.0 and sustainability in OSCM. Then, the second step (2) concerns the leverage of I4.0 initiatives (e.g., technologies) to achieve planet (energy, resource, and design), prosperity (flexibility, time-to-market cycles, quality, and cost/profit), and people (job quality, workforce capability, and social conditions) benefits, whilst also increasing the positive impact on the SDGs. This means reaping the benefits of S-OSCM4.0 from the correct balance of the 3Ps (people, planet, and prosperity) of the 2030 Agenda. As a result of this step, organisations can draw more value from their OSCM. Finally, the third step (3) concerns the alignment of S-OSCM4.0 priorities with SDGs. It represents the alignment of the organisation's objectives and goals (within its OSCM) under the new perspective of the S-OSCM4.0-the integration of the I4.0 platform (technologies and tools) and sustainability philosophies/practices to meet a Sustainable development agenda. This step also points to the need to link organisational 
goals/interests with the 2030 Agenda, focusing on seven of the seventeen SDGs (the proposed implications of which are presented in Section 4.2) that could potentially present a higher level of synergy, and could be achieved according to the moment (symbolised by the clock in Figure 8) and priorities of the corporate agenda. Thus, the correct interplay between managerial and global agendas is expected to favour a sustainable and inclusive digitization in operations and supply chains.

Hence, this framework can strategically support organisations in aligning their priorities with the SDGs [83], and in managing their contribution regarding the ten benefits of S-OSCM4.0. It potentially contributes to the driving forces of SDGs, which according to [84] are: public health, environmental concerns, resource value, climate change and inclusivity. As an example of the implementation of this three-step framework, organisations that wish to obtain (prioritise) a reduction in energy consumption [72] (a benefit to the planet) must adequately manage natural resources in order that they are not exceeded $[6,70]$, and should obtain a flexible infrastructure that enables more energy efficiency [64]. Additionally, suppose an organisation wants to focus on improving workforce capability [14] (a benefit to people). In that case, it must overcome knowledge and support challenges, such as the lack of technical expertise [57], and organisations should make use of I4.0 technologies such as wearable technologies [26] that facilitate safety training.

\subsection{Implications for the 2030 Agenda}

The present study also highlights seven research propositions (RPs) on the topic of S-OSCM4.0 as ready-made hypotheses for testing through empirical research. The propositions of this work are:

- RP1: Organisations with S-OSCM4.0 can positively contribute to reliable and modern energy services, and can facilitate access to clean energy research and technology, including renewable energy, energy efficiency, and more-advanced and cleaner fossilfuel technology (SDG\#7).

- RP2: Organisations with S-OSCM4.0 can positively contribute to sustainable economic growth by supporting productive activities and decent job creation (SDG\#8).

- RP3: Organisations with S-OSCM4.0 can positively contribute to the promotion of inclusive and sustainable industrialisation by fostering innovation through increased resource-use efficiency and the greater adoption of clean and environmentally sound technologies and industrial processes (SDG\#9).

- RP4: Organisations with S-OSCM4.0 can positively contribute to the reduction of inequality by empowering and promoting the socioeconomic inclusion of all and ensuring equal opportunities (SDG\#10).

- RP5: Organisations with S-OSCM4.0 can positively contribute to more inclusive, safe, resilient and sustainable cities through accessible, sustainable and smart transport systems (SDG\#11).

- RP6: Organisations with S-OSCM4.0 can positively contribute to the strengthening of the technological capacity to move towards more sustainable consumption and production patterns by reducing waste generation through prevention, reduction, recycling and reuse (SDG\#12).

- RP7: Organisations with S-OSCM4.0 can positively contribute to the promotion of multi-stakeholder partnerships that mobilise and share knowledge, expertise, technology and financial resources, in order to support the achievement of SD (SDG\#17).

By providing these seven research propositions for future studies on S-OSCM4.0 (from RP1 to RP7), this work aims to pave the way towards a better understanding of the ways in which organisations can overcome the challenges of I4.0-Sustainability integration in OSCM and unlock SD benefits headed toward the 2030 Agenda. 


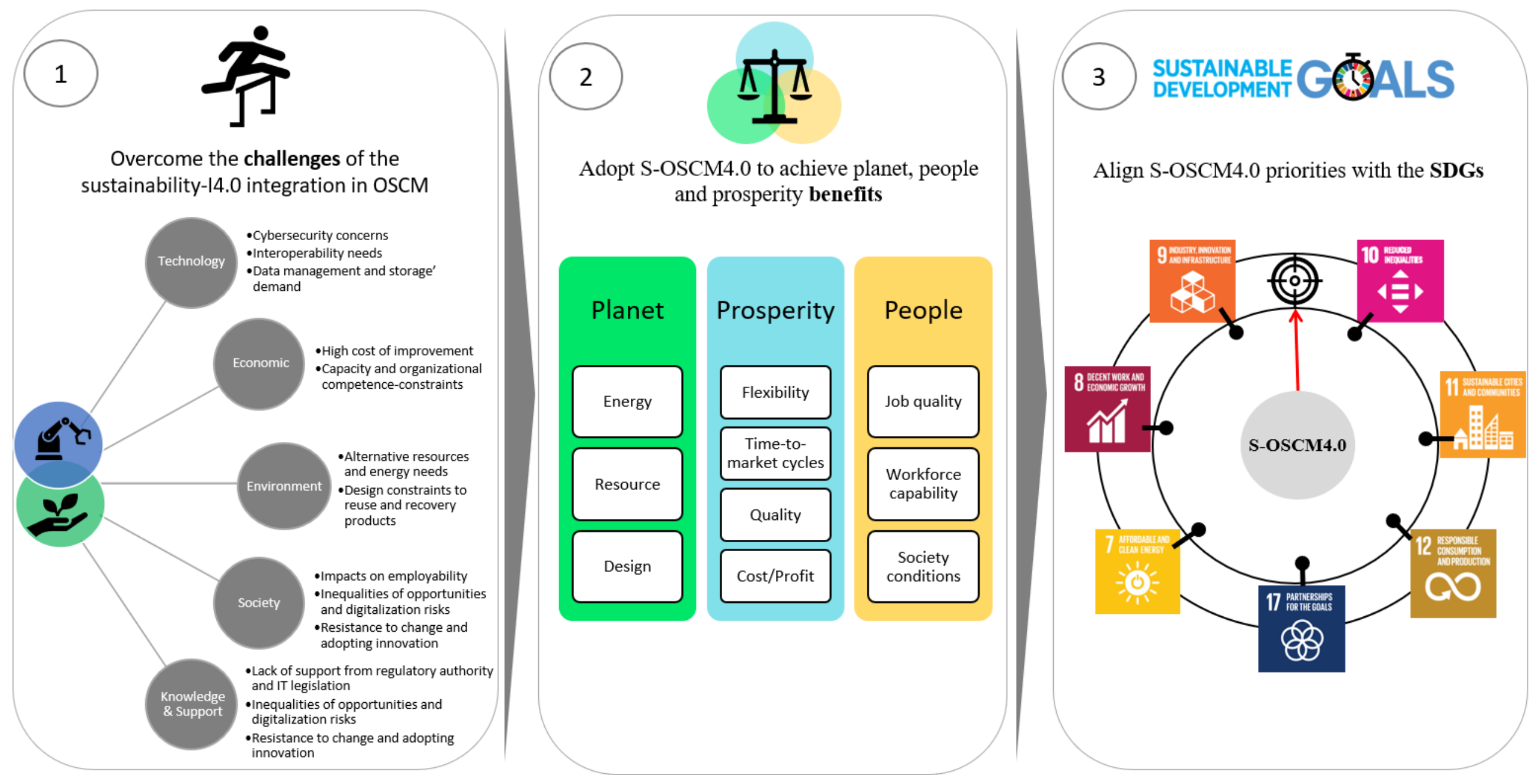

Figure 8. S-OSCM4.0 framework towards the 2030 Agenda. 


\section{Conclusions}

The emerging topic of I4.0, with its social end technical elements, has been associated with sustainable development within the OSCM of organisations, serving as a critical component of S-OSCM4.0. Within this context, this research addresses the need to improve the understanding of the integration of I4.0 and S-OSCM, offering a novel framework for the implementation of S-OSCM4.0 by aligning taxonomies of challenges and benefits headed toward the 2030 Agenda.

It is expected that the taxonomies proposed in this study not only clarify and bring consensus on the naming of the challenges and benefits of S-OSCM4.0 but also, more importantly, provide a framework as a valuable guide for the research and development of best practice management, public policy and new research [28]. This article is innovative in proposing a framework that combines novel concepts from the I4.0 and S-OSCM with the Sustainable Development Goals, thus providing new directions for future research. It represents a thorough and crucial essential advance in this emerging field (S-OSCM4.0).

The results of SLR with interactive taxonomy development offer theoretical and managerial contributions to S-OSCM4.0 [85]. From a theoretical point of view, this SLR generated two products: the taxonomies and a framework [30]. It is one of the initial efforts to contribute to the theory of S-OSCM4.0 and the relationships between the challenges and benefits of this new area. The proposed taxonomies can improve the specification of interventions in S-OSCM4.0, thus helping the replication, implementation and synthesis of evidence, and the proposed framework can facilitate the implementation of S-OSCM4.0, leading to the unlocking of the benefits of SD in line with the SDGs.

From a managerial point of view, the proposed framework can support OSCM professionals (as well as policy makers) to develop guidelines for the implementation of sustainable digitalisation. It addresses the lack of a standard structure that establishes links between the existing challenges and expected benefits to strategically guide organisations on the journey towards a S-OSCM4.0 aligned with the SDGs. Moreover, it contemplates sustainable digitalisation achievement leading to people, prosperity and planet benefits, offering practitioners a holistic view. Thus, the framework can guide practitioners towards the implementation of S-OSCM4.0 within their operations, aiding managers to face the challenges in achieving the benefits of SD in OSCM. Furthermore, it can be argued that testing the proposed framework can be a starting point for the implementation of S-OSCM4.0. The proposed framework sheds light on the potential of sustainable I4.0 in terms of the maximization of the company's contributions to the SDGs, aligning its course to ensure that sustainability is an outcome of the core business strategy.

This study can be developed further in order to overcome some of its limitations. First, the selection of Scopus and WoS databases may be one of the limitations of this article, as there may be articles outside these databases that may be relevant to the scope of the study, and the results of this research are limited to a select number of publications. Besides additional databases focused on the academic literature, one additional suggestion is the inclusion of databases that cover especially grey literature covering material from practitioners, e.g., following the guidelines proposed in [86]. There was a temporal limitation because the data were collected on a date, and if there are new authors or new articles, these will not be part of the selected portfolio of articles. An update of this research is also recommended, as suggested in different systematic literature reviews' guidelines (e.g., [39]). The author's perception which developed this research is limited, including the decision on the alignment with the topic and even the observations. Furthermore, as the focus was on articles from academic journals in English, articles from other languages were excluded. Finally, due to the identification of publications based on keywords, it is possible that publications that match the focus of the research were not found because they do not contain the necessary keywords in their titles or abstracts. Therefore, additional research could explore different keywords complementing the findings of this paper.

Second, it could be argued that testing the proposed framework may be a starting point for the implementation of S-OSCM4.0. The proposed framework can be presented 
to key stakeholders for refinement $[85,87,88]$, and should be validated by further studies, e.g., covering empirical approaches such as focus groups, interviews with experts in I4.0, and sustainability. We also suggest that applying the framework to different cultures, nations, and continents should further highlight the cultural aspects and implementation challenges that must be considered when adopting the ideas in this work. Exploring different contexts empirically through a panel of experts, case studies, or surveys can help in the generalization of the findings of this research.

Third, we also suggest conducting in-depth case studies in order to understand the 'soft side' of integrating I4.0 and sustainability in OSCM by qualitatively exploring benefits and challenges to S-OSCM4.0, or the extent to which the organisations can achieve these SD benefits. For example, innovative practices such as "green-circular premium" [89] can be studied in-depth in order to understand how the consumers not only increase the willingness to pay for products that implement green or circular transition but also accept the high price of renewable resources and the reused/recycled/recovered/bio-based materials which are used. This understanding should prove valuable to better promote and encourage the adoption of the various results from quantitative studies [73] resulting from the step-by-step framework.

Fourth, as a work based on theoretical suggestions, we strongly recommend that these RPs be developed further, by conducting qualitative research or by converting the propositions into hypotheses that will be tested through quantitative methods. Empirical quantitative studies may be conducted to analyse the S-OSCM4.0 constructs' relationships, using structural equation modelling [54] or by computing the intensity and prioritisation of the variables using multi-criteria decision-making approaches $[8,22]$. We also encourage further researchers to investigate the trade-off between the challenges and benefits to the achievement of S-OSCM4.0.

Finally, future research studies may also investigate the maturity of S-OSCM4.0 in the different industrial setups. It is expected that the proposed framework be adapted based on the OSCM4.0 model by [2] to have, as a differential, the possibility of comparing the OSCM sustainability of organizations from different industries.

Author Contributions: Conceptualisation, R.G.G.C., L.F.S., B.D.A., D.L.d.M.N. and O.L.G.Q.; methodology, R.G.G.C., L.F.S. and B.D.A.; software, R.G.G.C., L.F.S., B.D.A., D.L.d.M.N. and O.L.G.Q.; validation, R.G.G.C., L.F.S., B.D.A., D.L.d.M.N. and O.L.G.Q.; formal analysis, R.G.G.C., L.F.S., B.D.A., D.L.d.M.N. and O.L.G.Q.; investigation, R.G.G.C., L.F.S., B.D.A., D.L.d.M.N. and O.L.G.Q.; resources, R.G.G.C., L.F.S. and O.L.G.Q.; data curation, R.G.G.C., L.F.S., B.D.A., D.L.d.M.N. and O.L.G.Q.; writing-original draft preparation, R.G.G.C.; writing-review and editing, R.G.G.C., L.F.S., B.D.A., D.L.d.M.N. and O.L.G.Q.; visualisation, R.G.G.C., L.F.S., B.D.A., D.L.d.M.N. and O.L.G.Q.; supervision, R.G.G.C. and O.L.G.Q.; project administration, R.G.G.C., L.F.S. and O.L.G.Q.; funding acquisition, R.G.G.C., L.F.S. and O.L.G.Q. All authors have read and agreed to the published version of the manuscript.

Funding: This work was supported by the Coordenação de Aperfeiçoamento de Pessoal de Nível Superior-Brazil-CAPES (Finance Code 001), the Brazilian National Council for Scientific and Technological Development-CNPq (grant number 311757/2018-9), and the Carlos Chagas Filho Foundation for Research Support of the State of Rio de Janeiro-FAPERJ (grant number E-26/201.363/2021; E26/211.298/2021)

Institutional Review Board Statement: Not applicable.

Informed Consent Statement: Not applicable.

Data Availability Statement: Not applicable.

Conflicts of Interest: The authors declare no conflict of interest. 


\section{Appendix A}

Table A1. Summary of the articles reviewed.

\begin{tabular}{|c|c|}
\hline Source & Title \\
\hline [77] & Sustainable business models and structures for industry 4.0 \\
\hline$[90]$ & $\begin{array}{l}\text { Big data and predictive analytics for supply chain sustainability: A theory-driven } \\
\text { research agenda }\end{array}$ \\
\hline$[64]$ & $\begin{array}{l}\text { Energy management in manufacturing: Toward eco-factories of the future-A focus } \\
\text { group study }\end{array}$ \\
\hline [55] & Logistics 4.0 and emerging sustainable business models \\
\hline [79] & $\begin{array}{l}\text { Additive manufacturing in the wood-furniture sector: Sustainability of the } \\
\text { technology, benefits and limitations of adoption }\end{array}$ \\
\hline [16] & $\begin{array}{c}\text { Industry } 4.0 \text { and supply chain sustainability: framework and future research } \\
\text { directions }\end{array}$ \\
\hline [6] & $\begin{array}{l}\text { Industry } 4.0 \text { and Sustainability Implications: A Scenario-Based Analysis of the } \\
\text { Impacts and Challenges }\end{array}$ \\
\hline [8] & $\begin{array}{c}\text { Sustainable Industry } 4.0 \text { framework: A systematic literature review identifying the } \\
\text { current trends and future perspectives }\end{array}$ \\
\hline$[10]$ & $\begin{array}{c}\text { Evaluating challenges to Industry } 4.0 \text { initiatives for supply chain sustainability in } \\
\text { emerging economies }\end{array}$ \\
\hline [17] & $\begin{array}{c}\text { What Drives the Implementation of Industry 4.0? The Role of Opportunities and } \\
\text { Challenges in the Context of Sustainability }\end{array}$ \\
\hline [14] & $\begin{array}{l}\text { Industry } 4.0 \text { as enabler for a sustainable development: A qualitative assessment of } \\
\text { its ecological and social potential }\end{array}$ \\
\hline [73] & $\begin{array}{c}\text { Industry } 4.0 \text { and the circular economy: a proposed research agenda and original } \\
\text { roadmap for sustainable operations }\end{array}$ \\
\hline [52] & $\begin{array}{l}\text { Pharma Industry 4.0: Literature review and research opportunities in sustainable } \\
\text { pharmaceutical supply chains }\end{array}$ \\
\hline [5] & $\begin{array}{c}\text { When titans meet-Can industry } 4.0 \text { revolutionise the environmentally-sustainable } \\
\text { manufacturing wave? The role of critical success factors }\end{array}$ \\
\hline$[61]$ & $\begin{array}{c}\text { Exploring organizational sustainability of Industry } 4.0 \text { under the triple bottom line: } \\
\text { The case of a manufacturing company }\end{array}$ \\
\hline [91] & $\begin{array}{l}\text { Transformative sustainable business models in the light of the digital imperative-a } \\
\text { global business economics perspective }\end{array}$ \\
\hline [92] & Smart manufacturing \\
\hline [93] & $\begin{array}{l}\text { Can big data and predictive analytics improve social and environmental } \\
\text { sustainability? }\end{array}$ \\
\hline [12] & $\begin{array}{c}\text { A review of Internet of Things (IoT) embedded sustainable supply chain for } \\
\text { industry } 4.0 \text { requirements }\end{array}$ \\
\hline [56] & $\begin{array}{l}\text { A comprehensive review of big data analytics throughout product lifecycle to } \\
\text { support sustainable smart manufacturing: A framework, challenges and future } \\
\text { research directions }\end{array}$ \\
\hline [71] & $\begin{array}{c}\text { Linking big data analytics and operational sustainability practices for sustainable } \\
\text { business management }\end{array}$ \\
\hline [94] & $\begin{array}{l}\text { Big data for agri-food 4.0: Application to sustainability management for by-products } \\
\text { supply chain }\end{array}$ \\
\hline [18] & $\begin{array}{c}\text { Exploring Industry } 4.0 \text { technologies to enable circular economy practices in a } \\
\text { manufacturing context: A business model proposal }\end{array}$ \\
\hline
\end{tabular}


Table A1. Cont.

\begin{tabular}{|c|c|}
\hline Source & Title \\
\hline [80] & $\begin{array}{c}\text { Evaluation of the Relation between Lean Manufacturing, Industry 4.0, and } \\
\text { Sustainability }\end{array}$ \\
\hline [62] & $\begin{array}{l}\text { Development of a Risk Framework for Industry } 4.0 \text { in the Context of Sustainability } \\
\text { for Established Manufacturers }\end{array}$ \\
\hline [54] & $\begin{array}{l}\text { Big data analytics as an operational excellence approach to enhance sustainable } \\
\text { supply chain performance }\end{array}$ \\
\hline [58] & Blockchain for the future of sustainable supply chain management in Industry 4.0 \\
\hline [9] & $\begin{array}{l}\text { Digitally-enabled sustainable supply chains in the 21st century: A review and a } \\
\text { research agenda }\end{array}$ \\
\hline [75] & Sustainable manufacturing in Industry 4.0: an emerging research agenda \\
\hline [69] & Impact of Industry 4.0 on Environmental Sustainability \\
\hline [78] & Industry 4.0 technologies assessment: A sustainability perspective \\
\hline [23] & $\begin{array}{l}\text { The impact of digital technologies on economic and environmental performance in } \\
\text { the context of industry 4.0: A moderated mediation model }\end{array}$ \\
\hline [57] & $\begin{array}{c}\text { Synchronized Barriers for Circular Supply Chains In Industry 3.5/Industry } 4.0 \\
\text { Transition for Sustainable Resource Management }\end{array}$ \\
\hline [8] & $\begin{array}{l}\text { A framework to overcome sustainable supply chain challenges through solution } \\
\text { measures of industry } 4.0 \text { and circular economy: An automotive case }\end{array}$ \\
\hline [76] & $\begin{array}{l}\text { Measuring the implications of sustainable manufacturing in the context of industry } \\
\qquad 4.0\end{array}$ \\
\hline [74] & $\begin{array}{c}\text { Industry } 4.0 \text { as an enabler of sustainability diffusion in supply chain: an analysis of } \\
\text { influential strength of drivers in an emerging economy }\end{array}$ \\
\hline [95] & $\begin{array}{l}\text { Industry } 4.0 \text { and circular economy: Operational excellence for sustainable reverse } \\
\text { supply chain performance }\end{array}$ \\
\hline [13] & $\begin{array}{c}\text { Industry } 4.0 \text { sustainable supply chains: An application of an IoT enabled scrap metal } \\
\text { management solution }\end{array}$ \\
\hline [27] & $\begin{array}{l}\text { A framework to achieve sustainability in manufacturing organisations of developing } \\
\text { economies using industry } 4.0 \text { technologies' enablers }\end{array}$ \\
\hline [96] & $\begin{array}{l}\text { The sustainable development goals (SDGs) as a basis for innovation skills for } \\
\text { engineers in the industry } 4.0 \text { context }\end{array}$ \\
\hline [59] & $\begin{array}{l}\text { Blockchain-empowered sustainable manufacturing and product lifecycle } \\
\text { management in industry 4.0: A survey }\end{array}$ \\
\hline [68] & $\begin{array}{c}\text { Modeling the Industry 4.0 Adoption for Sustainable Production in Micro, Small and } \\
\text { Medium Enterprises }\end{array}$ \\
\hline [97] & $\begin{array}{l}\text { Relationships between industry } 4.0 \text {, sustainable manufacturing and circular } \\
\text { economy: proposal of a research framework }\end{array}$ \\
\hline [66] & Industry 4.0 , digitization, and opportunities for sustainability \\
\hline [63] & $\begin{array}{l}\text { A framework for operative and social sustainability functionalities in } \\
\text { Human-Centric Cyber-Physical Production Systems }\end{array}$ \\
\hline [67] & Opportunities for Socially Responsible Industry 4.s \\
\hline [53] & $\begin{array}{l}\text { Blockchain technology and the sustainable supply chain: Theoretically exploring } \\
\text { adoption barriers }\end{array}$ \\
\hline [65] & $\begin{array}{c}\text { Industry } 4.0 \text { adoption and 10R advance manufacturing capabilities for sustainable } \\
\text { development }\end{array}$ \\
\hline
\end{tabular}




\section{Appendix B}

Table A2. Benefits of S-OSCM4.0 and their potential alignment with Agenda 2030.

\begin{tabular}{|c|c|c|c|c|}
\hline Taxonomy & ID & Benefit & Source & SDG \\
\hline \multirow[t]{2}{*}{ Planet } & 1 & Energy & {$[5,14,26,56,59,62,66,74,75,77,78,80]$} & $\begin{array}{l}\text { SDG\#7: ensure universal access to affordable, reliable and } \\
\text { modern energy services (7.1); and facilitate access to clean } \\
\text { energy research and technology, including renewable } \\
\text { energy, energy efficiency and advanced and cleaner } \\
\text { fossil-fuel technology, and promote investment in energy } \\
\text { infrastructure and clean energy technology (7.2). }\end{array}$ \\
\hline & 2 & Resource & {$[5,6,9,12-14,17,26,52,56,58,60-62,66,68-71,74-76,78-80]$} & $\begin{array}{l}\text { SDG\#9: upgrade infrastructure and retrofit industries to } \\
\text { make them sustainable, with increased resource-use } \\
\text { efficiency and greater adoption of clean and } \\
\text { environmentally sound technologies and industrial } \\
\text { processes (9.4) } \\
\text { SDG\#12: achieve efficient use of natural resources (12.2); }\end{array}$ \\
\hline Taxonomy & 3 & Design & {$[5,10,56,66,71,79]$} & $\begin{array}{l}\text { SDG\#12: achieve the environmentally sound } \\
\text { management of chemicals and all wastes throughout their } \\
\text { life cycle, in accordance with agreed international } \\
\text { frameworks, and significantly reduce their release to air, } \\
\text { water and soil in to sminimise their adverse impacts on } \\
\text { human health and the environment (12.4); substantially } \\
\text { reduce waste generation through prevention, reduction, } \\
\text { recycling and reuse (12.5). }\end{array}$ \\
\hline
\end{tabular}

SDG\#8: achieve higher levels of economic productivity through diversification, technological upgrading and innovation, including through a focus on high value added and labor-intensive sectors (8.2);

\begin{tabular}{cccc}
\cline { 2 - 3 } Prosperity & 5 & $\begin{array}{c}\text { Time-to- } \\
\text { market } \\
\text { cycles }\end{array}$ & {$[9,17,56,63,66,76,77,79]$} \\
\cline { 2 - 4 } & & Quality & {$[17,56,61-63,66,69,73,79]$}
\end{tabular}

SDG\#9: Enhance scientific research, encouraging innovation and substantially increasing the number of research and development workers (9.5);

SDG\#8: support productive activities, creativity and innovation (8.5),

SDG\#9: develop quality, reliable, sustainable and resilient infrastructure (9.1)

SDG\#8: improve progressively, resource efficiency in consumption and production (8.4); SDG\#9: increase the access of small-scale industrial and other enterprises, in particular in developing countries, to financial services, and their integration into value chains and markets (9.3) SDG\#11: provide access to affordable, accessible and sustainable transport systems for all, improving road safety (11.2); SDG\#12: achieve the sustainable

7 Costs/Profit $\quad[6,9,13,16,17,26,54,56,60-63,66,68,69,71,74,76-80]$ management and efficient use of natural resources (12.2); SDG\#17: promote the development, transfer, dissemination and diffusion of environmentally sound technologies to developing countries on favorable terms (17.7);

SDG\#8: support decent job creation (8.3); achieve full and productive employment and decent work for all women and men, including for young people and persons with disabilities, and equal pay for work of equal value (8.5);

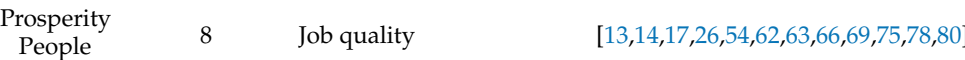

SDG\#8: substantially reduce the proportion of youth not in employment, education, or training (8.6);

SDG\#9: Upgrade the technological capabilities of

$9 \quad$ Workforce capability

$13,14,54,63,65,68,71,74,75,78,80]$ countries (9.5);

rticular developing

SDG\#12: support developing countries to strengthen

their scientific and technological capacity to move towards more sustainable patterns of consumption and production (12.a);

SDG\#10: empower and promote the social and economic inclusion of all, irrespective of age, sex, disability, race, ethnicity, origin, religion or economic or other status (10.2), ensure equal opportunity and reduce inequalities of outcome, including (10.3).

\section{References}

1. Koh, L.; Orzes, G.; Jia, F. The fourth industrial revolution (Industry 4.0): Technologies disruption on operations and supply chain management. Int. J. Oper. Prod. Manag. 2019, 39, 817-828. [CrossRef]

2. Caiado, R.G.G.; Scavarda, L.F.; Gavião, L.O.; Ivson, P.; Nascimento, D.L.D.M.; Garza-Reyes, J.A. A fuzzy rule-based industry 4.0 maturity model for operations and supply chain management. Int. J. Prod. Econ. 2020, 231, 107883. [CrossRef] 
3. Beier, G.; Ullrich, A.; Niehoff, S.; Reißig, M.; Habich, M. Industry 4.0: How it is defined from a sociotechnical perspective and how much sustainability it includes-A literature review. J. Clean. Prod. 2020, 259, 120856. [CrossRef]

4. Sony, M.; Naik, S. Technology in Society Industry 4.0 integration with sociotechnical systems theory: A sys-tematic review and proposed theoretical model. Technol. Soc. 2020, 61, 101248. [CrossRef]

5. De Sousa Jabbour, A.B.L.; Jabbour, C.J.C.; Foropon, C.; Godinho Filho, M. When titans meet-Can industry 4.0 revolutionise the environmentally-sustainable manufacturing wave? The role of critical success factors. Technol. Forecast. Soc. Chang. 2018, 132, 18-25. [CrossRef]

6. Bonilla, S.H.; Silva, H.R.O.; da Silva, M.T.; Gonçalves, R.F.; Sacomano, J.B. Industry 4.0 and Sustainability Implications: A Scenario-Based Analysis of the Impacts and Challenges. Sustainability 2018, 10, 3740. [CrossRef]

7. Kovács, G.; Kuula, M.; Seuring, S.; Blome, C. Operations adding value to society. Int. J. Oper. Prod. Manag. 2020, 40, 1293-1300. [CrossRef]

8. Yadav, G.; Luthra, S.; Jakhar, S.K.; Mangla, S.K.; Rai, D.P. A framework to overcome sustainable supply chain challenges through solution measures of industry 4.0 and circular economy: An automotive case. J. Clean. Prod. 2020, 254, 120112. [CrossRef]

9. Jabbour, C.J.C.; Fiorini, P.D.C.; Ndubisi, N.O.; Queiroz, M.M.; Piato, L. Digitally-enabled sustainable supply chains in the 21st century: A review and a research agenda. Sci. Total Environ. 2020, 725, 138177. [CrossRef]

10. Luthra, S.; Mangla, S.K. Evaluating challenges to Industry 4.0 initiatives for supply chain sustainability in emerging economies. Process Saf. Environ. Prot. 2018, 117, 168-179. [CrossRef]

11. Nhamo, G.; Nhemachena, C.; Nhamo, S. Using ICT indicators to measure readiness of countries to implement Industry 4.0 and the SDGs. Environ. Econ. Policy Stud. 2019, 22, 315-337. [CrossRef]

12. Manavalan, E.; Jayakrishna, K. A review of Internet of Things (IoT) embedded sustainable supply chain for industry 4.0 requirements. Comput. Ind. Eng. 2018, 127, 925-953. [CrossRef]

13. Mastos, T.D.; Nizamis, A.; Vafeiadis, T.; Alexopoulos, N.; Ntinas, C.; Gkortzis, D.; Papadopoulos, A.; Ioannidis, D.; Tzovaras, D. Industry 4.0 sustainable supply chains: An application of an IoT enabled scrap metal management solution. J. Clean. Prod. 2020, 269, 122377. [CrossRef]

14. Stock, T.; Obenaus, M.; Kunz, S.; Kohl, H. Industry 4.0 as enabler for a sustainable development: A qualitative assessment of its ecological and social potential. Process. Saf. Environ. Prot. 2018, 118, 254-267. [CrossRef]

15. Machado, E.; Scavarda, L.F.; Caiado, R.G.G.; Thomé, A.M.T. Barriers and Enablers for the Integration of Industry 4.0 and Sustainability in Supply Chains of MSMEs. Sustainability 2021, 13, 11664. [CrossRef]

16. Bag, S.; Telukdarie, A.; Pretorius, J.H.C.; Gupta, S. Industry 4.0 and supply chain sustainability: Framework and future research directions. Benchmarking Int. J. 2018, 28, 1410-1450. [CrossRef]

17. Müller, J.M.; Kiel, D.; Voigt, K.-I. What Drives the Implementation of Industry 4.0? The Role of Opportunities and Challenges in the Context of Sustainability. Sustainability 2018, 10, 247. [CrossRef]

18. Nascimento, D.L.M.; Alencastro, V.; Quelhas, O.L.G.; Caiado, R.G.G.; Garza-Reyes, J.A.; Rocha-Lona, L.; Tortorella, G. Exploring Industry 4.0 technologies to enable circular economy practices in a manufacturing context: A business model proposa. J. Manuf. Technol. Manag. 2019, 30, 607-627. [CrossRef]

19. Kristoffersen, E.; Mikalef, P.; Blomsma, F.; Li, J. Towards a business analytics capability for the circular economy. Technol. Forecast. Soc. Chang. 2021, 171, 120957. [CrossRef]

20. Kristoffersen, E.; Mikalef, P.; Blomsma, F.; Li, J. The effects of business analytics capability on circular economy implementation, resource orchestration capability, and firm performance. Int. J. Prod. Econ. 2021, 239, 108205. [CrossRef]

21. Kristoffersen, E. Towards a Smart Circular Economy: How Digital Technologies Can Support the Adoption of Circular Economy. Ph.D. Thesis, Norwegian University of Science and Technology, Trondheim, Norway, 2021.

22. do Carmo Silva, M.; Lima, G.B.; Gomes, C.F.; Rangel, L.A.; Caiado, R.G. A SMARTS-Choquet's approach for multicriteria decision aid applied to the innovation indexes in sustainability dimensions. Soft Comput. 2019, 23, 7117-7133. [CrossRef]

23. Li, Y.; Dai, J.; Cui, L. The impact of digital technologies on economic and environmental performance in the context of industry 4.0: A moderated mediation model. Int. J. Prod. Econ. 2020, 229, 107777. [CrossRef]

24. Scavarda, A.; Daú, G.; Scavarda, L.F.; Azevedo, B.D.; Korzenowski, A.L. Social and ecological approaches in urban interfaces: A sharing economy management framework. Sci. Total Environ. 2020, 713, 134407. [CrossRef] [PubMed]

25. Kiel, D.; Müller, J.M.; Arnold, C.; Voigt, K.I. Sustainable industrial value creation: Benefits and challenges of Industry 4.0. Int. J. Innov. Manag. 2017, 21, 1740015. [CrossRef]

26. Kamble, S.S.; Gunasekaran, A.; Gawankar, S.A. Sustainable Industry 4.0 framework: A systematic literature review identifying the current trends and future perspectives. Process Saf. Environ. Prot. 2018, 117, 408-425. [CrossRef]

27. Yadav, G.; Kumar, A.; Luthra, S.; Garza-Reyes, J.A.; Kumar, V.; Batista, L. A framework to achieve sustainability in manufacturing organisations of developing economies using industry 4.0 technologies' enablers. Comput. Ind. 2020, 122, 103280. [CrossRef]

28. Bashshur, R.; Shannon, G.; Krupinski, E.; Grigsby, J. The Taxonomy of Telemedicine. Telemed. E-Health 2011, 17, 484-494. [CrossRef] [PubMed]

29. Adams, N.E. Bloom's taxonomy of cognitive learning objectives. JMLA 2015, 103, 152. [CrossRef]

30. Torraco, R.J. Writing Integrative Literature Reviews: Guidelines and Examples. Hum. Resour. Dev. Rev. 2005, 4, 356-367. [CrossRef] 
31. Tranfield, D.; Denyer, D.; Smart, P. Towards a Methodology for Developing Evidence-Informed Management Knowledge by Means of Systematic Review. Br. J. Manag. 2003, 14, 207-222. [CrossRef]

32. Julianelli, V.; Caiado, R.G.G.; Scavarda, L.F.; Cruz, S.P.D.M.F. Interplay between reverse logistics and circular economy: Critical success factors-based taxonomy and framework. Resour. Conserv. Recycl. 2020, 158, 104784. [CrossRef]

33. Windsor, B.; Popovich, I.; Jordan, V.; Showell, M.; Shea, B.; Farquhar, C. Methodological quality of systematic reviews in subfertility: A comparison of Cochrane and non-Cochrane systematic reviews in assisted reproductive technologies. Hum. Reprod. 2012, 27, 3460-3466. [CrossRef]

34. Denyer, D.; Tranfield, D. Producing a systematic review. In The Sage Handbook of Organizational Research Methods; Buchanan, D.A., Bryman, A., Eds.; Sage Publications Ltd.: Thousand Oaks, CA, USA, 2009; pp. 671-689.

35. de Medeiros, J.F.; Ribeiro, J.L.D.; Cortimiglia, M.N. Success factors for environmentally sustainable product innovation: A systematic literature review. J. Clean. Prod. 2014, 65, 76-86. [CrossRef]

36. Garza-Reyes, J.A. Lean and green-A systematic review of the state of the art literature. J. Clean. Prod. 2015, 102, 18-29. [CrossRef]

37. Danese, P.; Manfè, V.; Romano, P. A Systematic Literature Review on Recent Lean Research: State-of-the-art and Future Directions. Int. J. Manag. Rev. 2017, 20, 579-605. [CrossRef]

38. Spina, G.; Caniato, F.; Luzzini, D.; Ronchi, S. Past, present and future trends of purchasing and supply management: An extensive literature review. Ind. Mark. Manag. 2013, 42, 1202-1212. [CrossRef]

39. Thomé, A.M.T.; Scavarda, L.F.; Scavarda, A.J. Conducting systematic literature review in operations management. Prod. Plan. Control 2016, 27, 408-420. [CrossRef]

40. Caiado, R.G.G.; Filho, W.L.; Quelhas, O.L.G.; Nascimento, D.L.D.M.; Ávila, L.V. A literature-based review on potentials and constraints in the implementation of the sustainable development goals. J. Clean. Prod. 2018, 198, 1276-1288. [CrossRef]

41. Mongeon, P.; Paul-Hus, A. The journal coverage of Web of Science and Scopus: A comparative analysis. Scientometrics 2016, 106, 213-228. [CrossRef]

42. Elkington, J. The Triple Bottom Line. Environmental Management: Readings and Cases; Sage Publications Ltd.: Thousand Oaks, CA, USA, 1997.

43. Moher, D.; Liberati, A.; Tetzlaff, J.; Altman, D.G. Prisma Group. Preferred reporting Items for systematic reviews and metaanalyses: The PRISMA statement. PLoS Med. 2009, 6, e1000097. [CrossRef]

44. Ceryno, P.; Scavarda, L.F.; Klingebiel, K.; Yuzgulec, G. Supply Chain Risk Management: A Content Analysis Approach. Int. J. Ind. Eng. Manag. 2013, 4, 141-150.

45. Mayring, P. Qualitative content analysis. In A Companion to Qualitative Research; Sage Publications Ltd.: Thousand Oaks, CA, USA, 2004; pp. 159-176.

46. Seuring, S.; Gold, S. Sustainability management beyond corporate boundaries: From stakeholders to performance. J. Clean. Prod. 2013, 56, 1-6. [CrossRef]

47. Dutra, J.; Busch, J. Enabling Knowledge Discovery: Taxonomy Development for NASA; Annual Meeting of the American Society for Science and Technology: Long Beach, CA, USA. Available online: http:/ /hdl.handle.net/2014/6569 (accessed on 20 November 2021)

48. Rich, P. The Organizational Taxonomy: Definition and Design. Acad. Manag. Rev. 1992, 17, 758-781. [CrossRef]

49. Eisenhardt, K.M. Making fast strategic decisions in high-velocity environments. Acad. Manag. J. 1989, 32, 543-576.

50. Frank, A.G.; Dalenogare, L.S.; Ayala, N.F. Industry 4.0 technologies: Implementation patterns in manufacturing companies. Int. J. Prod. Econ. 2019, 210, 15-26. [CrossRef]

51. Moktadir, A.; Ali, S.M.; Rajesh, R.; Paul, S.K. Modeling the interrelationships among barriers to sustainable supply chain management in leather industry. J. Clean. Prod. 2018, 181, 631-651. [CrossRef]

52. Ding, B. Pharma Industry 4.0: Literature review and research opportunities in sustainable pharmaceutical supply chains. Process Saf. Environ. Prot. 2018, 119, 115-130. [CrossRef]

53. Kouhizadeh, M.; Saberi, S.; Sarkis, J. Blockchain technology and the sustainable supply chain: Theoretically exploring adoption barriers. Int. J. Prod. Econ. 2020, 231, 107831. [CrossRef]

54. Bag, S.; Wood, L.C.; Xu, L.; Dhamija, P.; Kayikci, Y. Big data analytics as an operational excellence approach to enhance sustainable supply chain performance. Resour. Conserv. Recycl. 2019, 153, 104559. [CrossRef]

55. Strandhagen, J.O.; Vallandingham, L.R.; Fragapane, G.; Stangeland, A.B.H.; Sharma, N. Logistics 4.0 and emerging sustainable business models. Adv. Manuf. 2017, 5, 359-369. [CrossRef]

56. Ren, S.; Zhang, Y.; Liu, Y.; Sakao, T.; Huisingh, D.; Almeida, C.M.V.B. A comprehensive review of big data analytics throughout product lifecycle to support sustainable smart manufacturing: A framework, challenges and future research directions. J. Clean. Prod. 2018, 210, 1343-1365. [CrossRef]

57. Ozkan-Ozen, Y.D.; Kazancoglu, Y.; Mangla, S.K. Synchronized Barriers for Circular Supply Chains in Industry 3.5/Industry 4.0 Transition for Sustainable Resource Management. Resour. Conserv. Recycl. 2020, 161, 104986. [CrossRef]

58. Esmaeilian, B.; Sarkis, J.; Lewis, K.; Behdad, S. Blockchain for the future of sustainable supply chain management in Industry 4.0. Resour. Conserv. Recycl. 2020, 163, 105064. [CrossRef]

59. Leng, J.; Ruan, G.; Jiang, P.; Xu, K.; Liu, Q.; Zhou, X.; Liu, C. Blockchain-empowered sustainable manufacturing and product lifecycle management in industry 4.0: A survey. Renew. Sustain. Energy Rev. 2020, 132, 110112. [CrossRef]

60. Azevedo, B.D.; Scavarda, L.F.; Caiado, R.G.; Fuss, M. Improving urban household solid waste management in developing countries based on the German experience. Waste Manag. 2021, 120, 772-783. [CrossRef] 
61. Braccini, A.M.; Margherita, E.G. Exploring Organizational Sustainability of Industry 4.0 under the Triple Bottom Line: The Case of a Manufacturing Company. Sustainability 2019, 11, 36. [CrossRef]

62. Birkel, H.S.; Veile, J.W.; Müller, J.M.; Hartmann, E.; Voigt, K.-I. Development of a Risk Framework for Industry 4.0 in the Context of Sustainability for Established Manufacturers. Sustainability 2019, 11, 384. [CrossRef]

63. Pinzone, M.; Albè, F.; Orlandelli, D.; Barletta, I.; Berlin, C.; Johansson, B.; Taisch, M. A framework for operative and social sustainability functionalities in Human-Centric Cyber-Physical Production Systems. Comput. Ind. Eng. 2020, 139, 105132. [CrossRef]

64. May, G.; Stahl, B.; Taisch, M. Energy management in manufacturing: Toward eco-factories of the future-A focus group study. Appl. Energy 2016, 164, 628-638. [CrossRef]

65. Bag, S.; Gupta, S.; Kumar, S. Industry 4.0 adoption and 10R advance manufacturing capabilities for sustainable development. Int. J. Prod. Econ. 2020, 231, 107844. [CrossRef]

66. Ghobakhloo, M. Industry 4.0, digitization, and opportunities for sustainability. J. Clean. Prod. 2019, 252, 119869. [CrossRef]

67. Hahn, K. Opportunities for Socially Responsible Industry 4.s. IEEE Eng. Manag. Rev. 2020, 48, 63-70. [CrossRef]

68. Khanzode, A.; Sarma, P.; Mangla, S.K.; Yuan, H. Modeling the Industry 4.0 adoption for sustainable production in Micro, Small \& Medium Enterprises. J. Clean. Prod. 2020, 279, 123489. [CrossRef]

69. Oláh, J.; Aburumman, N.; Popp, J.; Khan, M.A.; Haddad, H.; Kitukutha, N. Impact of Industry 4.0 on Environmental Sustainability. Sustainability 2020, 12, 4674. [CrossRef]

70. Caiado, R.; Nascimento, D.; Quelhas, O.; Tortorella, G.; Rangel, L. Towards sustainability through green, lean and six sigma integration at service industry: Review and framework. Technol. Econ. Dev. Econ. 2018, 24, 1659-1678. [CrossRef]

71. Raut, R.D.; Mangla, S.K.; Narwane, V.S.; Gardas, B.B.; Priyadarshinee, P.; Narkhede, B.E. Linking big data analytics and operational sustainability practices for sustainable business management. J. Clean. Prod. 2019, 224, 10-24. [CrossRef]

72. Kamble, S.; Gunasekaran, A.; Dhone, N.C. Industry 4.0 and lean manufacturing practices for sustainable organisational performance in Indian manufacturing companies. Int. J. Prod. Res. 2019, 58, 1319-1337. [CrossRef]

73. de Sousa Jabbour, A.B.L.; Jabbour, C.J.C.; Godinho Filho, M.; Roubaud, D. Industry 4.0 and the circular economy: A proposed research agenda and original roadmap for sustainable operations. Ann. Oper. Res. 2018, 270, 273-286. [CrossRef]

74. Luthra, S.; Kumar, A.; Zavadskas, E.K.; Mangla, S.K.; Garza-Reyes, J.A. Industry 4.0 as an enabler of sustainability diffusion in supply chain: An analysis of influential strength of drivers in an emerging economy. Int. J. Prod. Res. 2019, 58, 1505-1521. [CrossRef]

75. Machado, C.G.; Winroth, M.P.; Da Silva, E.H.D.R. Sustainable manufacturing in Industry 4.0: An emerging research agenda. Int. J. Prod. Res. 2019, 58, 1462-1484. [CrossRef]

76. Ivascu, L. Measuring the Implications of Sustainable Manufacturing in the Context of Industry 4.0. Processes 2020, 8, 585. [CrossRef]

77. Prause, G. Sustainable Business Models and Structures for Industry 4.0. J. Secur. Sustain. Issues 2015, 5, 159-169. [CrossRef]

78. Bai, C.; Dallasega, P.; Orzes, G.; Sarkis, J. Industry 4.0 technologies assessment: A sustainability perspective. Int. J. Prod. Econ. 2020, 229, 107776. [CrossRef]

79. Murmura, F.; Bravi, L. Additive manufacturing in the wood-furniture sector. J. Manuf. Technol. Manag. 2017, $29,350-371$. [CrossRef]

80. Varela, L.; Araújo, A.; Ávila, P.; Castro, H.; Putnik, G. Evaluation of the Relation between Lean Manufacturing, Industry 4.0, and Sustainability. Sustainability 2019, 11, 1439. [CrossRef]

81. Muniz, M.V.P.; Lima, G.B.A.; Caiado, R.G.G.; Quelhas, O.L.G. Bow tie to improve risk management of natural gas pipelines. Process. Saf. Prog. 2017, 37, 169-175. [CrossRef]

82. Shahzad, M.; Qu, Y.; Zafar, A.U.; Appolloni, A. Does the interaction between the knowledge management process and sustainable development practices boost corporate green innovation? Bus. Strat. Environ. 2021, 30, 4206-4222. [CrossRef]

83. WBCSD. SDG Compass-The Guide for Business Action on the SDGs; WBCSD: Geneva, Switzerland, 2015.

84. Mathiyazhagan, K.; Agarwal, V.; Appolloni, A.; Saikouk, T.; Gnanavelbabu, A. Integrating lean and agile practices for achieving global sustainability goals in Indian manufacturing industries. Technol. Forecast. Soc. Chang. 2021, 171, 120982. [CrossRef]

85. Nascimento, D.L.D.M.; Quelhas, O.L.G.; Caiado, R.; Tortorella, G.L.; Garza-Reyes, J.A.; Rocha-Lona, L. A lean six sigma framework for continuous and incremental improvement in the oil and gas sector. Int. J. Lean Six Sigma 2019, 11, 577-595. [CrossRef]

86. Adams, R.J.; Smart, P.; Huff, A.S. Shades of Grey: Guidelines for Working with the Grey Literature in Systematic Reviews for Management and Organizational Studies. Int. J. Manag. Rev. 2016, 19, 432-454. [CrossRef]

87. Nascimento, D.L.D.M.; Caiado, R.; Tortorella, G.; Ivson, P.; Meiriño, M. Digital Obeya Room: Exploring the synergies between BIM and lean for visual construction management. Innov. Infrastruct. Solut. 2018, 3, 19. [CrossRef]

88. Tortorella, G.; Nascimento, D.L.D.M.; Caiado, R.; Posada, J.G.A.; Sawhney, R. How do different generations contribute to the development of a learning organization in companies undergoing a lean production implementation? Learn. Organ. 2019, 27, 101-115. [CrossRef]

89. Appolloni, A.; Jabbour, C.J.C.; D'Adamo, I.; Gastaldi, M.; Settembre-Blundo, D. Green recovery in the mature manufacturing industry: The role of the green-circular premium and sustainability certification in innovative efforts. Ecol. Econ. 2021, 193, 107311. [CrossRef] 
90. Hazen, B.T.; Skipper, J.B.; Ezell, J.D.; Boone, C.A. Big data and predictive analytics for supply chain sustainability: A theory-driven research agenda. Comput. Ind. Eng. 2016, 101, 592-598. [CrossRef]

91. Brenner, B. Transformative Sustainable Business Models in the Light of the Digital Imperative-A Global Business Economics Perspective. Sustainability 2018, 10, 4428. [CrossRef]

92. Kusiak, A. Smart manufacturing. Int. J. Prod. Res. 2017, 56, 508-517. [CrossRef]

93. Dubey, R.; Gunasekaran, A.; Childe, S.J.; Papadopoulos, T.; Luo, Z.; Wamba, S.F.; Roubaud, D. Can big data and predictive analytics improve social and environmental sustainability? Technol. Forecast. Soc. Chang. 2019, 144, 534-545. [CrossRef]

94. Belaud, J.-P.; Prioux, N.; Vialle, C.; Sablayrolles, C. Big data for agri-food 4.0: Application to sustainability management for by-products supply chain. Comput. Ind. 2019, 111, 41-50. [CrossRef]

95. Dev, N.K.; Shankar, R.; Qaiser, F.H. Industry 4.0 and circular economy: Operational excellence for sustainable reverse supply chain performance. Resour. Conserv. Recycl. 2020, 153. [CrossRef]

96. Rivera, F.M.-L.; Hermosilla, P.; Delgadillo, J.; Echeverría, D. The Sustainable Development Goals (SDGs) as a Basis for Innovation Skills for Engineers in the Industry 4.0 Context. Sustainability 2020, 12, 6622. [CrossRef]

97. Bag, S.; Pretorius, J.H.C. Relationships between industry 4.0, sustainable manufacturing and circular economy: Proposal of a research framework. Int. J. Organ. Anal. 2020. [CrossRef] 